\title{
Reclaiming Traffic Influenced Urban Residual Spaces for the Public in Colombo, Sri Lanka
}

\author{
Anuka Weththasinghe, Janaka Wijesundara \\ Department of Architecture, University of Moratuwa, Sri Lanka
}

\begin{abstract}
Although highly populated districts in Sri Lanka, like Colombo, suffer from decrement of open public spaces, there are many unused areas within the city. Most of them have existed because of traffic related activities and transport infrastructure needs. Therefore, revitalizing them is a challenging task. It is important to explore the possibilities of reclaiming traffic related-urban residual spaces for public use. This study investigates most suitable reclaiming possibilities in selected urban residual spaces with their usage and spatial qualities. The research collected data through questionnaires, interviews and systematic observations. Four cases were selected which varied in terms of their physical layout patterns, usage and location setting.

The study reveals that spatial and usage qualities of traffic related residual spaces vary, mainly due to location type and the extent of the site. People feel insecure due to vehicular movement. Observations show to what extent it is possible to mitigate such issues through design and planning strategies. Although the traffic-related residual spaces have residual symptoms, respondents believe that there is a possibility to reclaim those spaces for public use. Every residual space has unique appropriation / intervention possibilities. Evaluation of these can help select the most suitable reclaiming possibility for residual spaces. The paper also examines the idea of public-private partnerships as a strategy to evade residual symptoms and allow better management and control of reclaimed public spaces.
\end{abstract}

Keywords: Urban Residual spaces, Reclaiming of unused lands, Traffic related spaces, Spatial and usage qualities, appropriation, Colombo City. 


\section{Urban residual spaces}

Theorists have defined urban residual spaces as lost spaces, non-spaces, and leftover spaces. According to Trancik, a lost space is:

"the left over unstructured landscape at the base of the high rise towers or the sunken plazas away from the flow of pedestrian activity in the city ,...they are the Romans land along the edges of freeways that nobody cares about maintaining much less using....also the abandon water fronts, train yards, vacated military sites and industrial complexes. They are the vacant blight-clearance sites-remnants of the urban renewal days-that were, for a multitude of reasons never redeveloped" (1986:3)

Trancik (1986) defines 'lost space' as 'the undesirable urban areas that are in need of redesign, anti-space, making no positive contribution to the surroundings of users". Winterbottomm (2000) describes three types of residual spaces: 'non-spaces', 'leftover spaces', and 'dual-use spaces'. He uses the term 'dual-used space' for areas, which function at a certain time with certain functions and become residual during other times. Further, he also refers to 'left over spaces' as un-programmed spaces detached from surrounding spaces. Rilvin (2007) suggests that people also used less designed spaces in their surroundings instead of using plazas and public squares. $\mathrm{He}$ uses the term 'found spaces' for those spaces that are located in convenient locations which have easy access and high visibility.

According to occupation patterns of leftover spaces, Alanyali, (2009) argues that leftovers are characterized by misuse, underuse and 'appropriation'. Based upon these three aspects, she concludes six typologies of leftover spaces as seen in Turky referred to as underutilized, potentially exploitable, abandoned, appropriated, obsolete and unproductive. According to Khalil \& Eissa,

"Urban residuals offer a potential alternative to the scarecity of open spaces.this alternative should be seriously considered by governments instead of depending completly on vacant plots of land-which are usualy a scace resource.the sucess of formal interventions or the permanance of appropriations in such spaces unravels a social agreement of accepting such interventions". (2013;120)

Today, urban land demand is excessive due to rapid population growth. Urban open land for public spaces are rapidly decreasing. Only $7.05 \%$ of open spaces existed in 1996 according to land use distribution in Colombo. (City of Colombo Development Plan, 1996). In 2013, it has decreased by $6.5 \%$ (Urban Transport System Development Project by JICA-Final Report, August 2014). There, the spaces used as open public spaces are minimum. The city needs urban parks, community parks, local parks and mini parks according to the hierarchical structure and general characteristics of urban centers (National Physical Plan of Sri Lanka, 2030). Therefore, smart usage of urban land is necessary in the city. Though there are many unused areas within the Colombo district, there is little attention to revitalization. 
Most residual spaces within the city come into being because of traffic related solutions. It is observed that the general attitude towards urban residual open space is that, it could not be used in any other useful manner. Although there are many studies related to urban spaces and their characteristics in Sri Lanka, research on urban residual spaces are scarce. A study on "Reclaiming residual spaces for the public: A Case Study from the City of Cairo" (Khalil \& Eissa, 2013) shows the reclaiming possibilities of residual spaces for the public in Egypt which can be enumerated in Sri Lanka.

\section{The causative factors of residual space}

Trancik (1986) argues that low control, undefined ownership and lack of management are the reasons for emerging 'lost' spaces. Alanyali, (2009) refers to lack of control and maintenance as a reason for leftover spaces. Further, she has identified two scenarios for a space to become a leftover space. The first are the non-designed places by authorities, therefore they do not serve the public. Second, there are places designed by authorities but are no longer used.

"....two scenarios for a space to become leftover; first, a space never having its share of design by the authorities and therefore it doesn't serve the public and those spaces are usually characterized by a ruined disorderly appearance and second, a space which was once designed by the authorities but has been subjected to deterioration and became no longer used." (as cited in Khalil \& Eissa,2013;107)

\section{Social -Spatial understanding of residual spaces}

Madanipour (1996) says that the attempt to integrate the social and physical dimensions of space, or in other words to contextualize the physical space into human practices, is an important aspect of our understanding of space. Thus, it is necessary to consider social and physical dimensions together.

\section{Spatial qualities}

Alanyali, (2009) refers to lack of boundaries and disorderly appearance as significant qualities of leftover spaces. She says,

"Space can be measured: it has defined and perceivable boundaries; it is discontinuous in principle, closed, static, yet serial in composition. Anti-space, on the other hand, is shapeless, continuous, lacking perceivable edges of form" (as cited in Trancik, 1986; 61)

A Number of spatial qualities have been studied; namely; easy accessibility, security level, site boundaries, site topography, uniformity of form, area of site, sites location, neighboring facilities, site's proximity to heavy circulation routes . (Khalil \& Eissa, 2013) Khalil \& Eissa, write that:

"Site's accessibility could be dangerous, easy or unfeasible which affects possibilities of appropriation. A site's visibility affects its exposure and defines whether it would be noticed by vehicles moving on a high speed or pedestrians- and thus defines the potential customers. Also, the area of the site affects the amount of appropriators it could host and impacts the types of activities assigned to it. Qualities 
referring to the site within its context include neighboring facilities which may provide the site with a high pedestrians' flow. .... A site's location within the city is also a factor that might attract or repel appropriators." (2013;113)

\section{Usage qualities}

"There is no logic that can be superimposed on the city. People make it, and it is to them, not buildings, that we must fit our plans" (Jacobs, 1958;160). According to Tuan, (1977;36) "The human being, by his mere presence, imposes a schema on space.....he notes its absence when he is lost..... "In the absence of the right people and things, places quickly drained of meaning so that their lastingness is an irritation rather than a comfort." (Tuan, 1977;140)

Alanyali (2009) argues that leftover spaces signify underuse, misuse and 'appropriation'. Based on that, she produces six typologies that exist in the Turkish context as underutilized, potentially exploitable, abandoned, appropriated, obsolete and unproductive. According to her, the usage qualities are the indicators of residually. Khalil \& Eissa (2013) also say, "Usage qualities of the site explain its current occupancy patterns. A space could be occupied on certain days of the week and abandoned on others....Previous functions of a site may also affect its appropriation pattern". Khalil \& Eissa $(2013 ; 113)$ consider pre and post-intervention usage qualities of residual spaces as below; pre-intervention usage qualities, use for site, users of site, time of use, frequency of use post-intervention usage qualitiesintervention activity, intervention body, intervention time, intervention frequency.

As Khalil \& Eissa $(2013 ; 108)$ write "residual spaces are often acted upon and become informally modified by users to host various activities. This informal modification is referred to as appropriation". Korosec et al. (1976) suggest that appropriation activities lay under one of the two categories: urging activities fulfilling a necessary need or optional activities such as recreation, and entertainment. Gehl (1987) further writes about those nessesary optional activities and says that the outdoor activities in public spaces can be divided in to three categories: necessary, optional and social activities. Nessasary activities include 'those that are more or less compulsory'; optional activities are those 'pursuits that are participated in, if there is wish to do and if time and place make it possible' social activities are 'all activities that depend on the persence of others in public space'. He further explains that 'when the quility of outdooor areas is good, optional activities occur with increasing frequency. Furthermore, as levels of optional activities rise, the number of social activities usually increases substantially $(1987 ; 13)$.

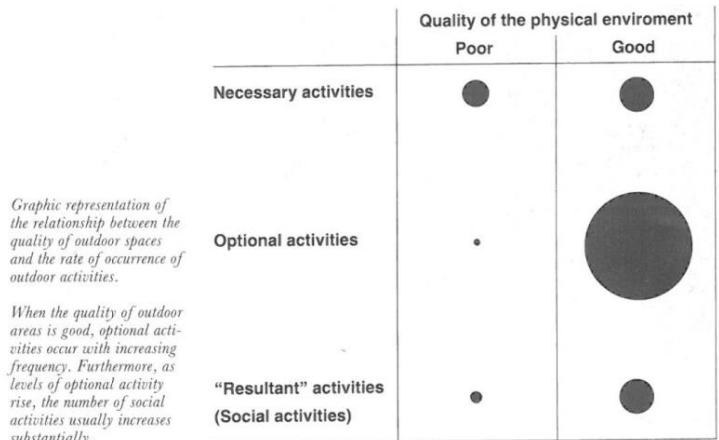

Table 1: Relationship between activities and quality of the physical environment Source- Gehl, J.,1987;13 


\section{Manifestation of urban residual space}

Tancik (1983) identifies unused sunken plazas away from the flow of pedestrian activity, abandoned water front, train yards, vacated military sites, areas beneath highways as 'lost space'. Further, according to Rilvin (1986), strips of sidewalks isolated from surroundings, islands, street intersections \& squares were geologically set off from surrounding space as 'found spaces'. Loukaitou-Sideris (1996) identifies decaying parks \& playgrounds as 'cracks in the city'. Cisman (2005) recognizes the gaps between one thing and another, collisions of scale and uses, leftover spaces under, over and along elevated highways and railway lines, or large urban voids and ruined places, fenced parks invisible from outside as "sight out of sight". Alanyali (2009) identifies unbuildable areas, interstitial zones, space related to circulation routes, abandoned as in $\mathrm{x}$-function sites, neglected (designed but not used), vacant buildable lands as 'leftover spaces'. Khalil \& Eissa (2013) defines the residual spaces as "inactive publicly owned latent pieces of land that are potentially exploitable".

According to many theorists, inactiveness, public ownerships and lack of maintenances are the common features of residual spaces although they have named them differently. According to literature, train yards, areas beneath highways, street intersections, street islands and squares are geologically set off from surrounding space, and hence can be identified as residual spaces. Among these leftover spaces under/over and along elevated highways and railway lines could be considered as traffic related residual spaces.

\section{Revitalizing urban residual spaces}

Trancik argues that "we need to reclaim these lost spaces by transforming them in to opportunities for development...existing public plazas, streets, and parking lots that are presently dysfunctional and incompatible with their contexts can be transformed in to viable open spaces" (1986;5) Similarly, according to Khalil \& Eissa,

"Urban residuals offer a potential alternative to the scarecity of open spaces.this alternative should be seriously considered by governments instead of depending completly on vacant plots of land, which are usualy a scace resource. The sucess of formal interventions or the permanance of appropriations in such spaces unravels a social agreement of accepting such interventions". (2013;120)

Further, they propose that the interventions upon residual spaces could be either formal or informal. Formal interventions manifest in approaches by government or organizations with pre-planned activities. Informal interventions manifest in appropriation. Accordingly, the revitalizing approach is a 'transformation' and 'a potential alternative' for open, dysfunctional spaces with considered appropriations by users.

\section{Framework for examining Revitalizing possibility}

Khalil \& Eissa (2013) present a list of factors that "decide whether a leftover space is likely to be appropriated or not, and could portray persumed modes of 
appropriation". Khalil \& Eissa (2013) state that although the residual spaces have different forms, "they all prove to be latent spaces with a potential for better utilization". Further, they discovered that "formal and informal interventions of such spaces improve their utilization, either through leisurly or nessasary activities".

Table 2: Physical and usage qualities of residual spaces

Source- Khalil, M.H., \& Eissa, D.M., (2013)

\begin{tabular}{|c|c|c|c|}
\hline \multirow{10}{*}{ 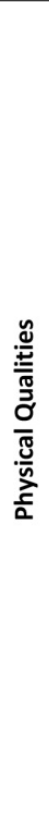 } & \multirow{7}{*}{ 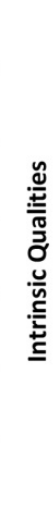 } & Accessibility & Safe, Dangerous \\
\hline & & Security level & High, Average, Low \\
\hline & & Visibility & Exposed, Hidden \\
\hline & & Site boundaries & Defined- Loose \\
\hline & & Site topography & Flat, Hilly \\
\hline & & Uniformity of form & Regular, Irregular \\
\hline & & Area of site & Tight, Spacious \\
\hline & \multirow{3}{*}{ 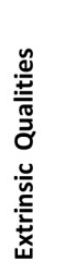 } & Site's location & Peripheral, Central \\
\hline & & $\begin{array}{l}\text { Neighboring } \\
\text { facilities/assets }\end{array}$ & $\begin{array}{l}\text { Views, Transportation } \\
\text { facilities,...etc. }\end{array}$ \\
\hline & & $\begin{array}{l}\text { Site's proximity to heavy } \\
\text { circulation routes }\end{array}$ & Roads or Pedestrians Paths \\
\hline \multirow{4}{*}{\multicolumn{2}{|c|}{ 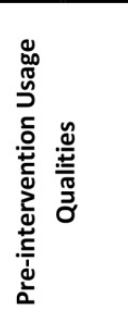 }} & Current use for site & $\begin{array}{l}\text { Vending, Recreation, etc., } \\
\text { or None }\end{array}$ \\
\hline & & Current users of site & Locals, Externals \\
\hline & & Time of current use & Day, Night \\
\hline & & Previous use for site & Industrial, cultural, etc. \\
\hline
\end{tabular}

This paper presents a study that enumerated the Cairo Study (2013) for examining the reclaiming possibilities of residual spaces for the public in Sri Lanka is The main research issue was to ascertain the possibilities of reclaiming traffic related urban residual spaces for public use.

The study employed a quantitative approach to examine four cases. A qualitative study helped to identify some implications of the objectives. Table 3 shows the method used in each stage. It outlines the main research objectives, data collection tools/methods. 
Table 3: Summery of methodology

\begin{tabular}{|l|l|l|}
\hline Research Objectives & Data needed & Data collection tools/method \\
\hline $\begin{array}{l}\text { 1. Examine a theoretical framework to } \\
\text { identify and define the residual spaces, and } \\
\text { their social -spatial characteristics. }\end{array}$ & Definition for urban residual spaces & $\begin{array}{l}\text { Literature review. } \\
\text { Use the framework used by Khalil \& } \\
\text { Eissa (2013) for identifying social- } \\
\text { spatial characteristics with authors' } \\
\text { improvements. }\end{array}$ \\
\hline $\begin{array}{l}\text { 2. Examine a theoretical framework to } \\
\text { measure the impact level of identified social- } \\
\text { spatial characteristics for reclaiming urban } \\
\text { residual spaces }\end{array}$ & $\begin{array}{l}\text { Users' perceptions/author's } \\
\text { observations about identified social- } \\
\text { spatial characteristics }\end{array}$ & $\begin{array}{l}\text { Structured questionnaire (allowed to present } \\
\text { reasons behind the selections), } \\
\text { Systematic observations } \\
\text { Activity logs. }\end{array}$ \\
\hline $\begin{array}{l}\text { 3.Identify the reclaiming possibilities for } \\
\text { selected urban residual spaces as public } \\
\text { space }\end{array}$ & $\begin{array}{l}\text { Analyzed data (Users' } \\
\text { perceptions/author's observations } \\
\text { about identified social-spatial } \\
\text { characteristics) }\end{array}$ & \\
\hline
\end{tabular}

\section{Selected Cases}

Four different case studies were selected. They have been divided into three main categories: Open side space - C1-BJ, Open middle space - C2-KJ, C4-MJ and Underneath middle space - C3-DF.The key factors of those cases are summarized in the table below.

Table 4: Summary of selected cases

\begin{tabular}{|l|l|l|l|l|}
\hline Case & Case 1-BJ & Case 2 -KJ & Case 3 -DF & Case 4 -MJ \\
\hline Name & $\begin{array}{l}\text { Side space of } \\
\text { Bambalapitiya } \\
\text { roudabout }\end{array}$ & $\begin{array}{l}\text { Roundabout at } \\
\text { Kottawa junction }\end{array}$ & $\begin{array}{l}\text { Underneath } \\
\text { space of } \\
\text { Dehiwala } \\
\text { flyover }\end{array}$ & $\begin{array}{l}\text { Roundabout at Maradana } \\
\text { junction }\end{array}$ \\
\hline Location & Colombo 04 & Kottawa & Dehiwala & Maradana, Colombo 10 \\
\hline $\begin{array}{l}\text { Characteri } \\
\text { stics }\end{array}$ & $\begin{array}{l}\text { open Lenear,long } \\
\text {,Side space of the } \\
\text { street }\end{array}$ & $\begin{array}{l}\text { Open,triangular } \\
\text { space created by } \\
\text { streets }\end{array}$ & $\begin{array}{l}\text { Open Linear } \\
\text { space in } \\
\text { between roads }\end{array}$ & $\begin{array}{l}\text { Open,triangular } \\
\text { space created by streets }\end{array}$ \\
\hline $\begin{array}{l}\text { Present } \\
\text { usage }\end{array}$ & $\begin{array}{l}\text { Unorganized } \\
\text { parking }\end{array}$ & $\begin{array}{l}\text { Paved area with } \\
\text { "Bo "shrine }\end{array}$ & Parking & $\begin{array}{l}\text { Landscaped } \\
\text { area }\end{array}$ \\
\hline
\end{tabular}

\section{Sampling and data collection}

Each case study involved sixty randomly selected sample users. They have answered the questionnaire at the selected sites. The surveys took place during two days inclusive of weekdays and Sunday in order to analyze the difference. Ten users were interviewed at every period (Morning, Afternoon and Evening).

\section{Introduction to selected cases}

\section{Case Study 01 - Side space of Bambalapitiya roudabout (C1-BJ)}

Recently, because of the new traffic plan in 2011, the road running in between Galle Road and R.A De Mel Mawatha has been converted to a one-way road. Earlier 
it was a two-way road and there was a center island with a water feature (See Fig: 3 ). According to the new plan, the center island was combined with a neat bus stand created with open side spaces. A small milk bar and other small structures that existed before have been removed.

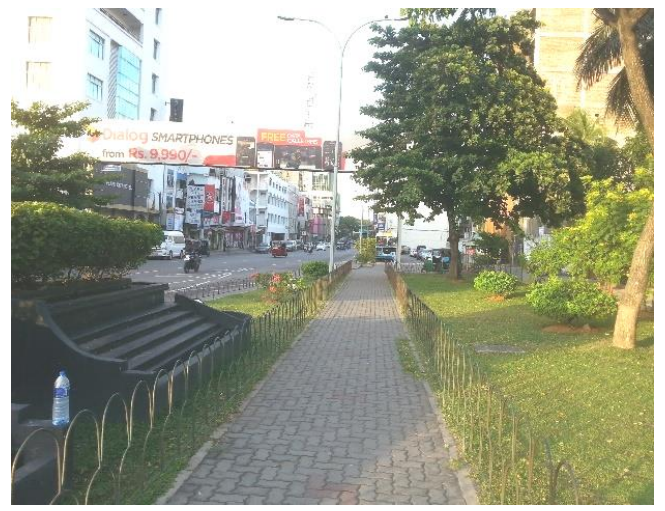

Fig 1: Lawn area, image from Galle Road Source: Author

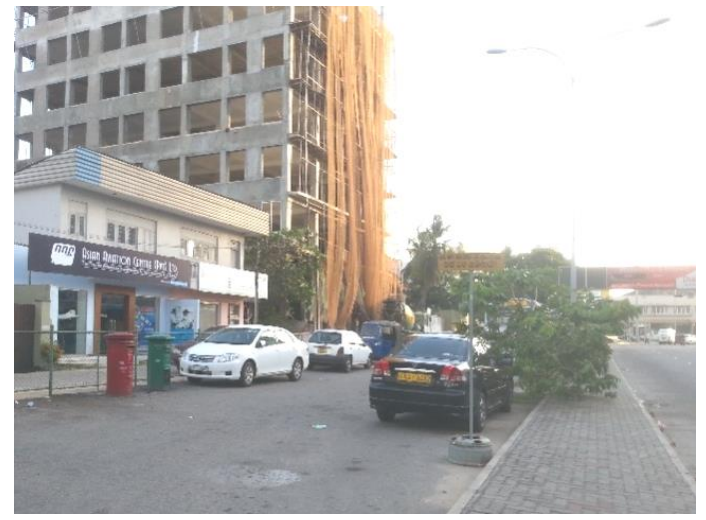

Fig 2: C.T.B bus stand Source: Author

Today, the side space accomodates the Ceylon Transportation Board (CTB) bus stand, Three-Wheeler Park and open landscaped area, which are barricaded by a fence. In front of the side-space, there is a public parking space. Kadawatha Bambalapitiya bus service starts from this bus stand. This side space is owned by the Road Development Authority (RDA) and CTB and maintained by Colombo Municipal Council (CMC). Although private vehicles are not allowed to park in the CTB bus stand, people tend to park their private vehicles making the area more congested.

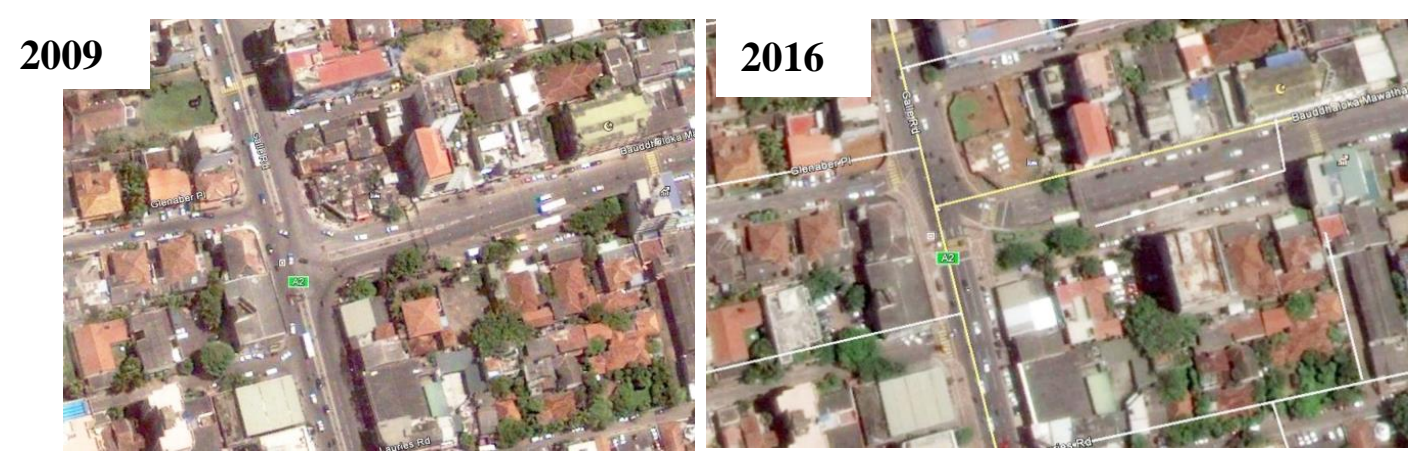

Fig 3: Transformation of space Source: Google Earth

\section{Indications of residually}

The area is poorly designed. The existing parking areas are not properly demarcated. People park their vehicles wherever they desire. The lawn areas were covered by fences. The water feature does not suit the space. This is an example for identified strips of sidewalks, which Rilvin (1986) calls 'found spaces'. 


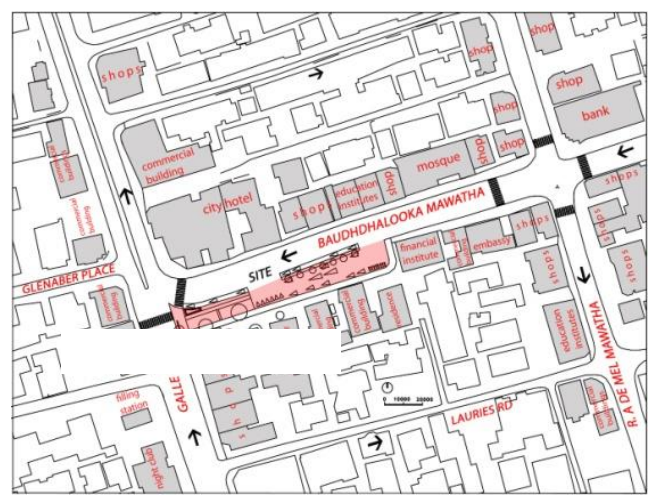

Fig 4: Bambalapitiya junction -Micro Context Source: Author

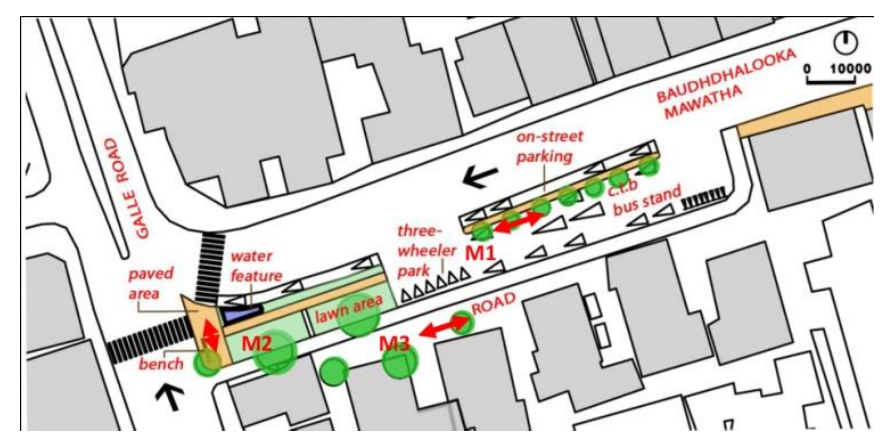

Fig 5: Bambalapitiya side space-existing plan ;User's movements with directions-M1- user's movement 1, M2- user's movement 2, M3- user's movement 3,

Source: Author

\section{Case Study 02- Roundabout at Kottawa junction (C2-KJ)}

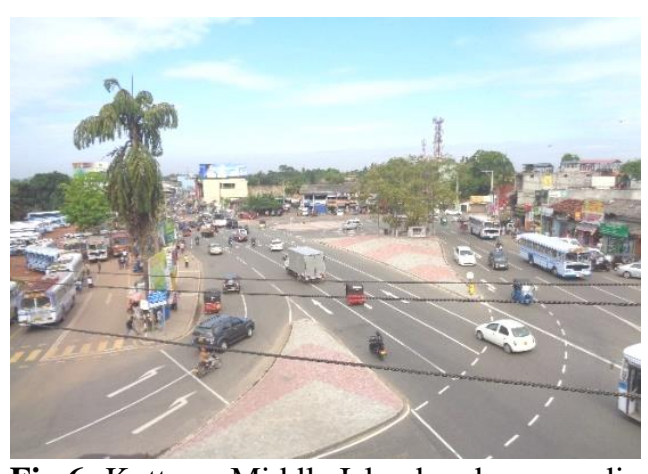

Fig 6: Kottawa Middle Island and surrounding Source: Author

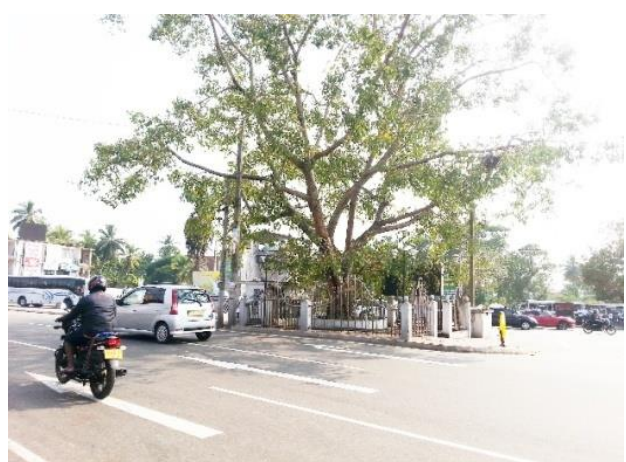

Fig 7: Bo shrine in the Middle Island Source: Author

The selected island is located in the middle of this junction with a 'Bo' tree. The earlier traffic plan (2015) has been changed in 2016. Previously, the center island was comparatively larger (see Fig: 8) which has been used as part of the bus stand. There was also a small shrine that people used to go often and worship. According to the new development plan, a part of the bus stand was removed from this middle space and the large middle island was divided into two individual islands. 

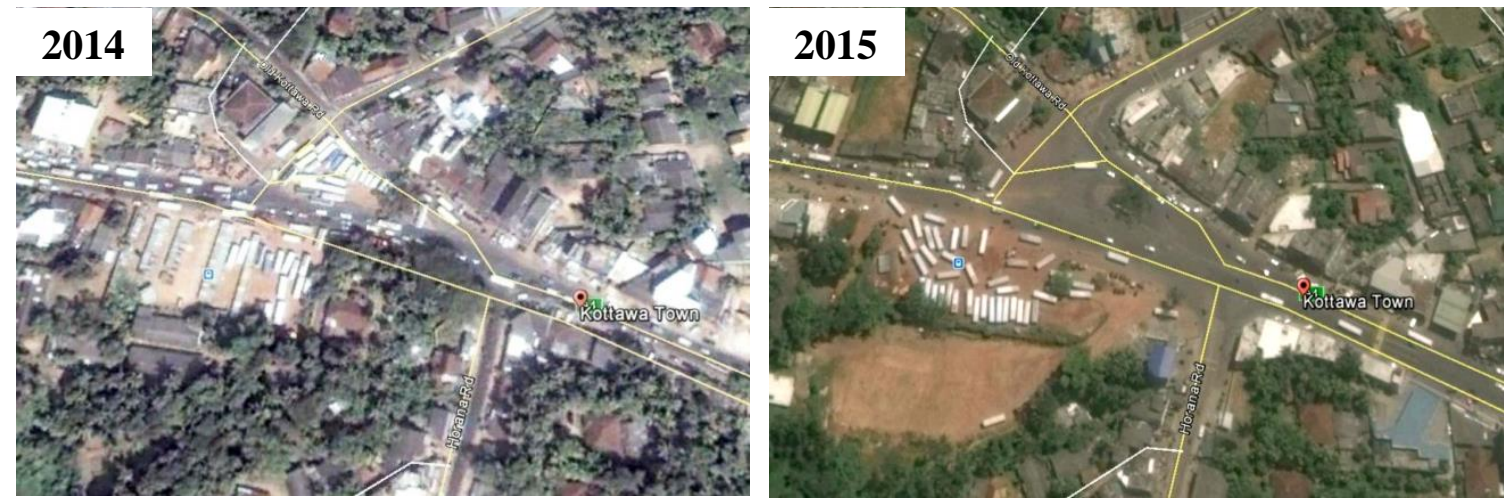

Fig 8: Transformation of Kottawa junction Source: Google Earth

Now both center islands have been paved with cement blocks and the 'Bo' tree has been left with a small shrine in one island. The Road Development Authority owns the place and Municipal Council maintains it.

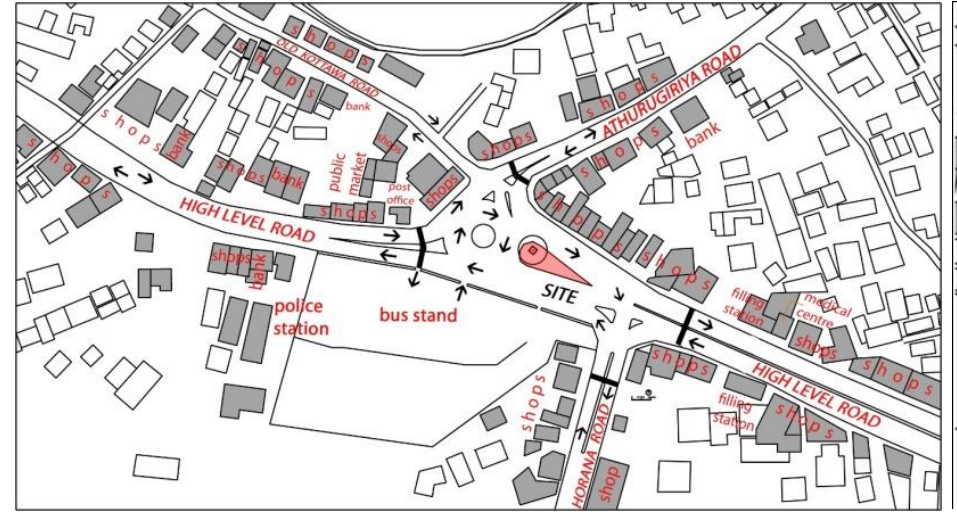

Fig 9: Kottawa middle island micro context Source: Author

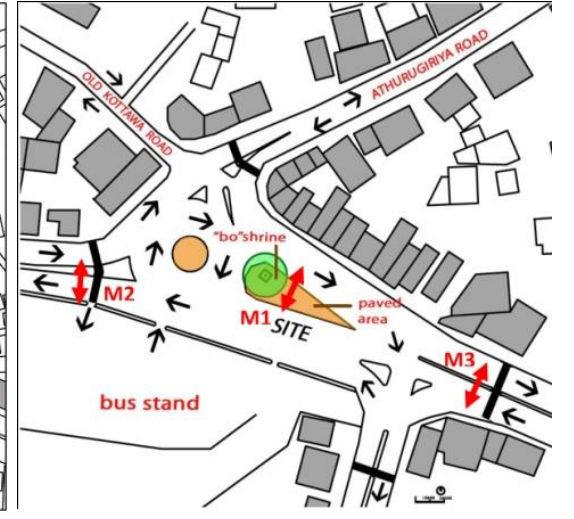

Fig 10: Middle island-KJ User's movements with directions

M1-user's movement 1, M2- user's movement 2, M3- user's movement 3 Source: Author

\section{Indications of residually}

The selected island is located in the middle of the junction. Center islands are paved in cement paving. It is related to the 'islands' which was described by Rilvin (1986) as a 'found space'. According to Alanyali (2009), this is a 'space related to circulation routes'. Further, it has indeterminate spatial qualities according to Rilvin (1986).

\section{Case Study 03- Underneath space of Dehiwala flyover (C3-DF)}

Dehiwala junction that connects Galle Road, Srimath D.B Jayathilake Mawatha and station road is another location. The fly over was built over Galle road at Dehiwala junction in 2009 as a solution for traffic congestion during peak hours. It is a two-lane flyover which is $337 \mathrm{~m}$ long and $7.35 \mathrm{~m}$ wide. The underneath space is 
currently used as a parking space and there are two pedestrian crossings under the fly over. This underneath space belongs to RDA and is maintained by the Municipal Council.

\section{Indications of residuality}

The underneath space is currently used as an unplanned and uncontrolled parking space. It is related to the "leftover spaces under ...elevated highways" as Crisman (2005), and also as "areas beneath highway" Trancik (1983) explains. Crisman (2005) uses the term "sight out of sight" to describe such abandoned usage quality.

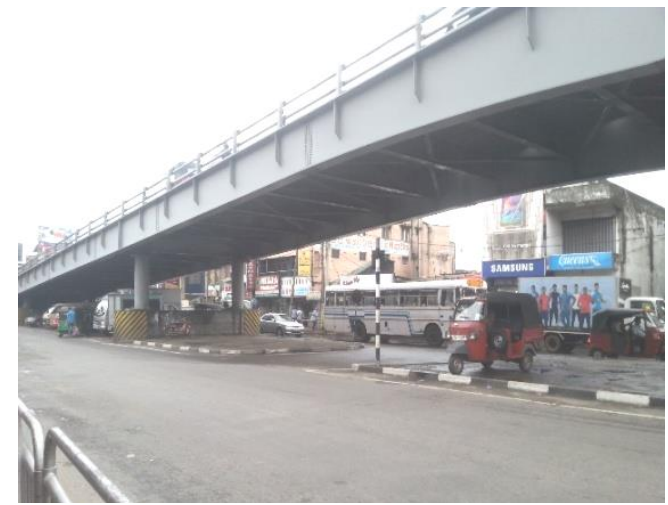

Fig11: Dehiwala flyovers and it's underneath space Source: Author

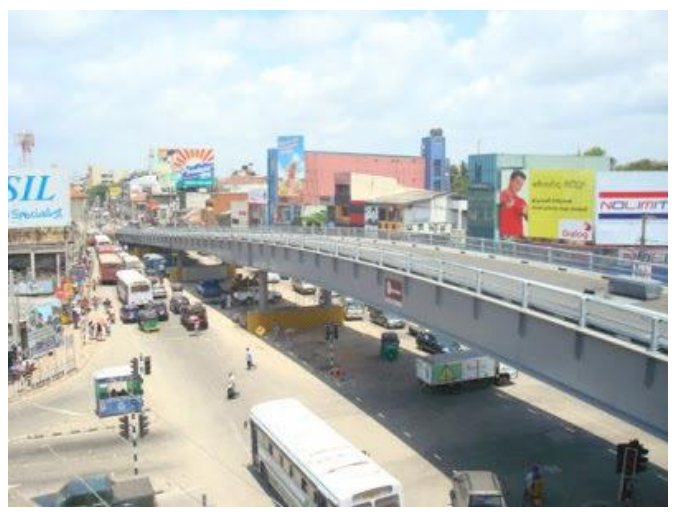

Fig12: Dehiwala flyovers and it's underneath space Source: Author

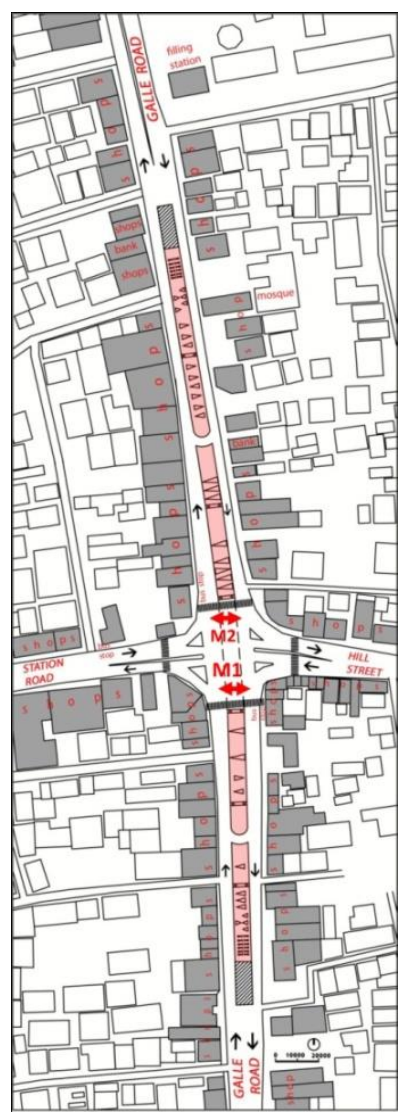

Fig 13: Dehiwala junction-macro plan

M1-user's movement 1, M2- user's movement 2

User's movements with directionsM1-user's movement 1, M2- user's movement 2. Source-Author

\section{Case 04-Rounderbout at Maradana junction-(C4-MJ)}

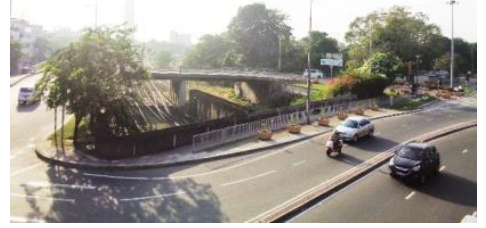

Fig14: Maradana middle space with void Source: Author

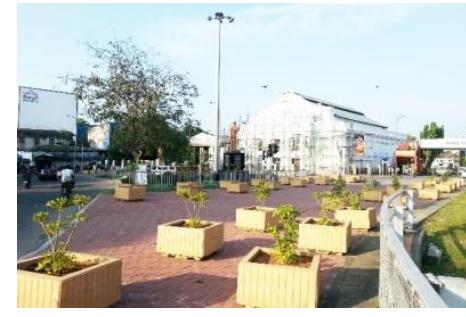

Fig15: Maradana middle space-paved path way Source: Author 
The island is located at Maradana Junction. It consists of a landscape and a void area generated by road bridges. Earlier, the void spaces and landscape areas were divided by a middle road. However, after the new traffic proposals, middle road was closed by combining the two parts and Panchikawaththa Road converted to a one-way road. Railway tracks run under the void space. (see Fig.16)

2005

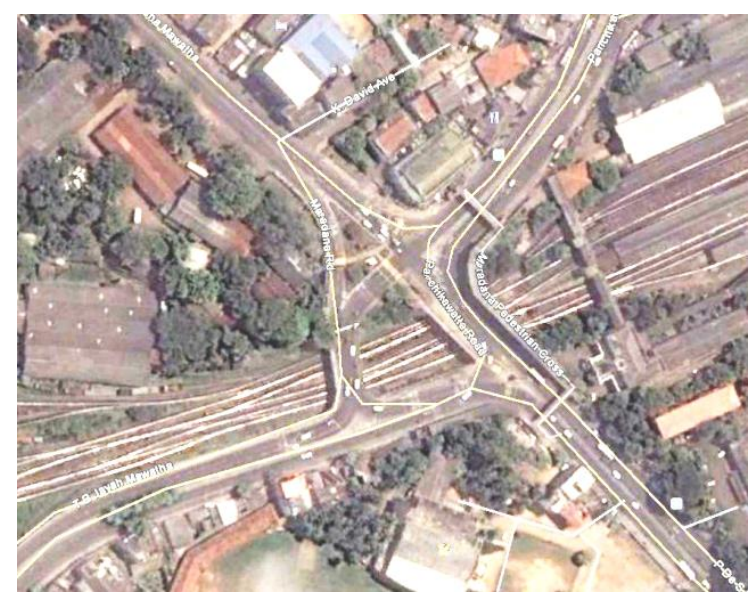

2016

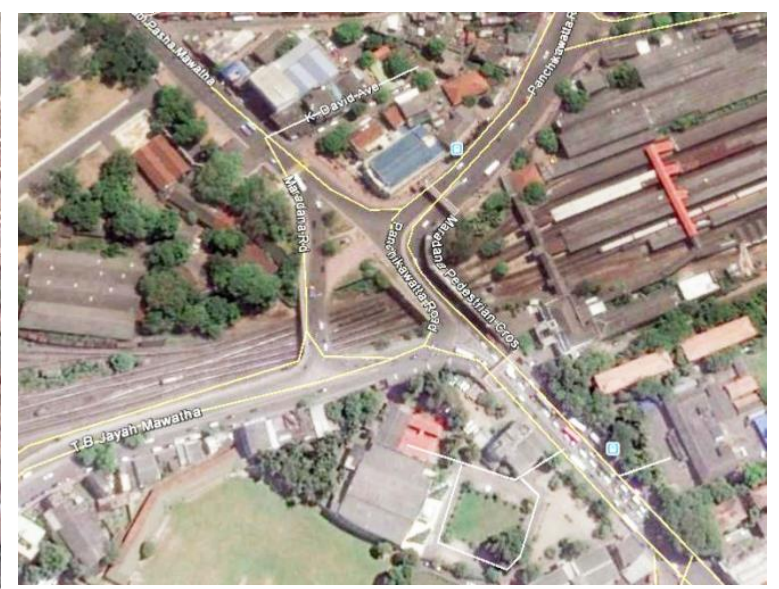

Fig. 16: Transformation of Maradana middle space

Source: Google Earth

This space is used as a landscaped area with flowerpots and a statue. This space belongs to R.D.A and maintained by C.M.C.

\section{Symptoms of residuality}

Presently, there is no proper activity planned except a mere pass-by. Original designs were changed and now it has become an unplanned space. It belongs to the category of islands as a 'lost space' as explained by Rivlin (1986). Leftover spaces over the railway line are explained by Crisman (2005) as sites out of sight.
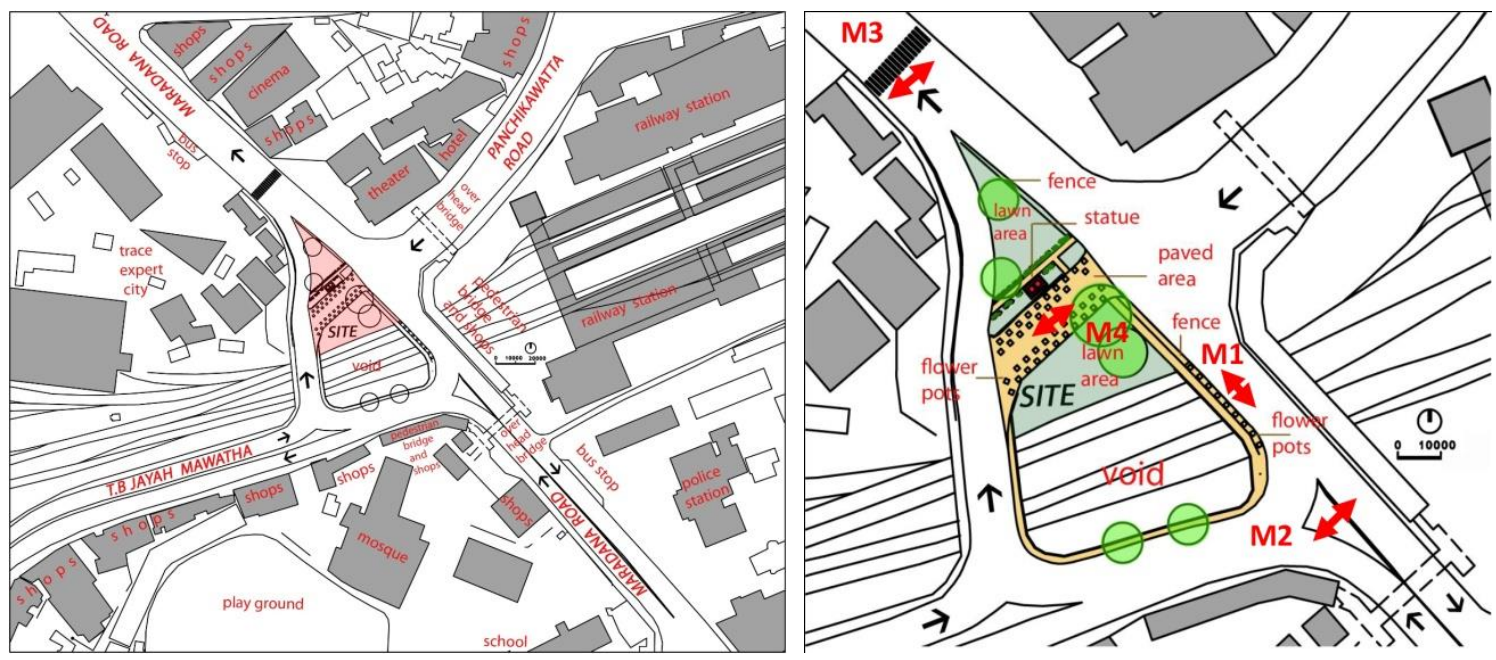

Fig18: Maradana middle space-micro context plan. User's movements with directions-M1-user's movement 1, M2user's movement 2, M3- user's movement 3, M4- user's movement 4: 


\section{Comparison of case studies}

\section{Impact level of physical characteristics}

Table 5: physical characteristics comparison

\begin{tabular}{|c|c|c|c|c|c|}
\hline Case & $\begin{array}{l}\text { Uniformi } \\
\text { ty of } \\
\text { form }\end{array}$ & Area of the site & $\begin{array}{l}\text { Site } \\
\text { location }\end{array}$ & $\begin{array}{l}\text { Site } \\
\text { boundaries }\end{array}$ & Neighborhood facilities \\
\hline C1-BJ & $\begin{array}{l}\text { Open, } \\
\text { Regular, } \\
\text { leaner } \\
\text { flat }\end{array}$ & $\begin{array}{l}\text { Spacious area } \\
1390 \text { Smwidth } \\
12.5 \mathrm{~m}(\mathrm{max}) \\
\text { Length } 118 \mathrm{~m}\end{array}$ & $\begin{array}{l}\text { Periphera } \\
\text { I side } \\
\text { space }\end{array}$ & $\begin{array}{l}\text { Well defined } \\
\text { by two roads, } \\
\text { and a multi- } \\
\text { story } \\
\text { building. }\end{array}$ & $\begin{array}{l}\text { City hotel, Mosque, private } \\
\text { educational institutes, shops, night } \\
\text { club, financial institutes, fashion } \\
\text { stores, shopping complexes } \\
\text { adjacent to the place. }\end{array}$ \\
\hline $\mathrm{C} 2-\mathrm{KJ}$ & $\begin{array}{l}\text { Open, } \\
\text { Leaner, } \\
\text { triangula, } \\
\text { flat }\end{array}$ & $\begin{array}{l}\text { Not a spacious, Tight Area } \\
1230 \mathrm{Sm} \text { Width } \\
25 \mathrm{~m} \text { (max) } \\
\text { Length } 85 \mathrm{~m}\end{array}$ & $\begin{array}{l}\text { Center, } \\
\text { middle } \\
\text { space }\end{array}$ & $\begin{array}{l}\text { Well } \\
\text { defined by } \\
\text { surrounding } \\
\text { main roads. }\end{array}$ & $\begin{array}{l}\text { Public market, police station, bus } \\
\text { stand, post office, } \\
\text { financial institutes and shops are } \\
\text { located around these immediate } \\
\text { surroundings }\end{array}$ \\
\hline C3-DF & $\begin{array}{l}\text { Open, } \\
\text { regular, } \\
\text { underneath } \\
\text { space }\end{array}$ & $\begin{array}{l}\text { Spacious } \\
\text { Area } \\
2170 \mathrm{Sm} \\
\text { Width } 7.5 \mathrm{~m} \\
\text { Length } 282 \mathrm{~m}\end{array}$ & $\begin{array}{l}\text { Center } \\
\text {,middle } \\
\text { space }\end{array}$ & $\begin{array}{l}\text { Well defined } \\
\text { by } \\
\text { surrounding } \\
\text { main road. }\end{array}$ & $\begin{array}{l}\text { Bus stand, railway station, fashion } \\
\text { stores and shops are located } \\
\text { around these immediate } \\
\text { surroundings }\end{array}$ \\
\hline C4-MJ & $\begin{array}{l}\text { Open, } \\
\text {,triangular, } \\
\text { flat }\end{array}$ & $\begin{array}{l}\text { Spacious than C2-KJ } \\
\text { Area } 1560 \mathrm{Sm} \\
3400 \mathrm{Sm} \\
\text { (with void) } \\
\text { Width } 46 \mathrm{~m} \\
\text { Length } 70 \mathrm{~m}\end{array}$ & $\begin{array}{l}\text { Center, } \\
\text { middle } \\
\text { space } \\
\text { With corner } \\
\text { void }\end{array}$ & $\begin{array}{l}\text { Well defined } \\
\text { by } \\
\text { surrounding } \\
\text { main road. } \\
\text { It's also has } \\
\text { boundary } \\
\text { fences. }\end{array}$ & $\begin{array}{l}\text { Railway station, Tracie expert city } \\
\text { (IT city), cinema, Elphiniston } \\
\text { Theatre, Tower Hall, Hotels, Zahira } \\
\text { college, Police station and shops } \\
\text { are located in this immediate } \\
\text { surrounding area }\end{array}$ \\
\hline
\end{tabular}

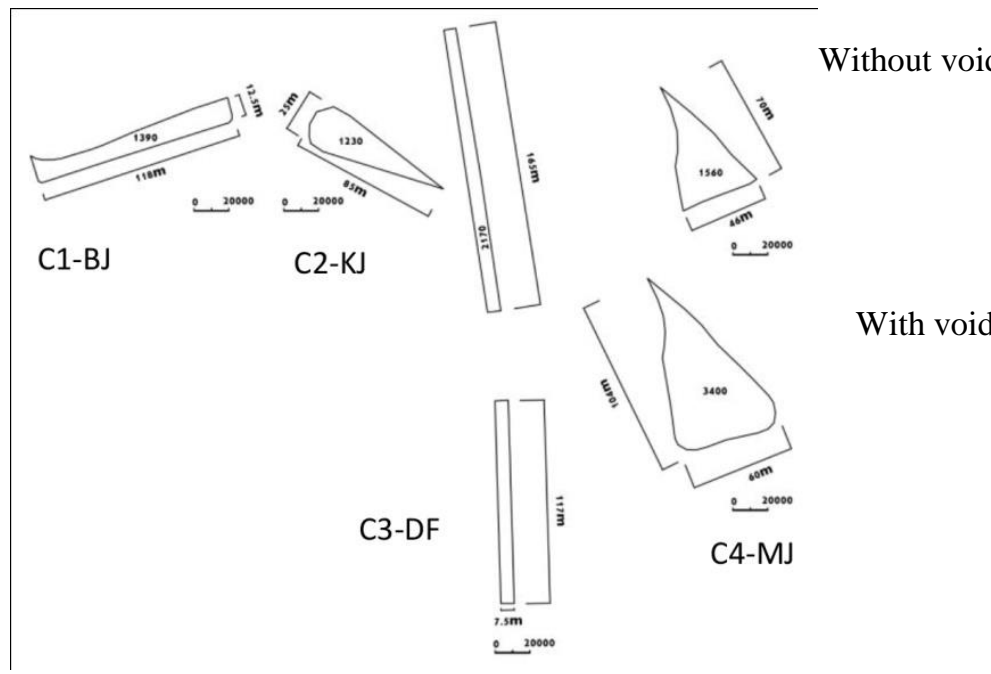

Site area

- $\mathrm{C} 3-\mathrm{DF}>\mathrm{C} 4-\mathrm{MJ}>\mathrm{C} 1-\mathrm{BJ}>\mathrm{C} 2-\mathrm{KJ}$

Fig 19: Site area comparison

Source: Author 
According to the above site area comparison, C3-DF has a larger area. C2-KJ has a small site and the usable area is reduced due to the triangular shape. There is an opportunity to increase the area of the C4-MJ by adding the void space. It doubles the existing land area of the C4-MJ.

\section{$\underline{\text { User perceptions }}$}

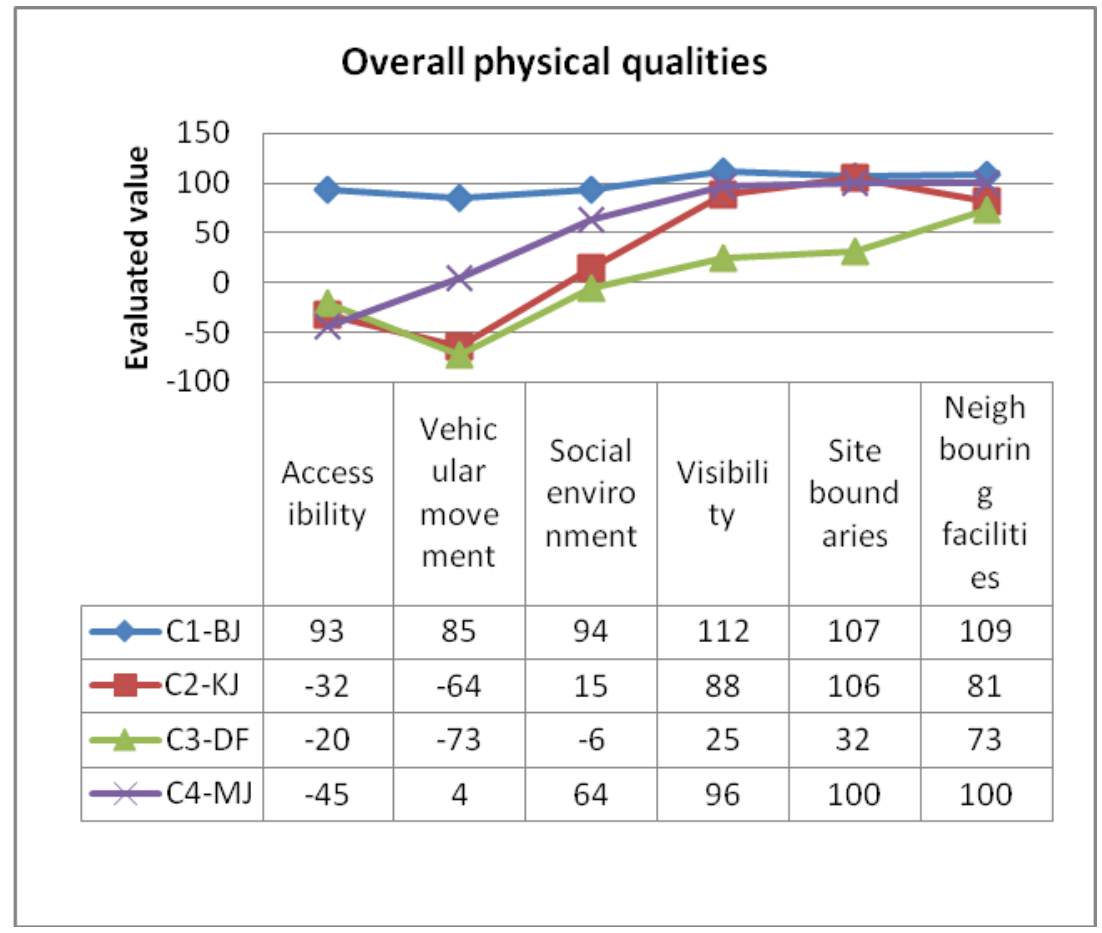

Fig 20: Survey result-overall physical qualities-all cases

\section{Accessibility}

\section{Source: Author}

User perceptions show that $\mathrm{C} 1$ is a place, which has the highest accessibility while C2, C4 have lower values. People can easily access the $\mathrm{C} 1$. There are three pedestrian crossings to reach this place from main roads. Vehicles can easily reach and drop people off.

In the cases of $\mathrm{C} 4$ and $\mathrm{C} 2$, People cannot easily access the place. Presently there are no pedestrian crossings to reach this place from the main roads. It is very difficult to reach this place due to heavy traffic flow in and around the main roads. There is an overhead pedestrian bridge in Case 4 to cross the main roads. However, reasonable numbers of people tend to cross the middle island without using the overhead bridge despite the danger. 


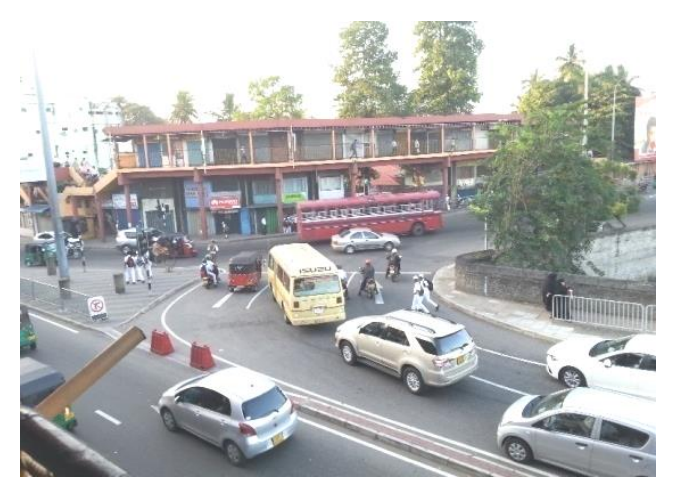

Fig 21: Pedestrian movement-M2 (C4-MJ) Source: Author

There are two pedestrian crossings with traffic lights to facilitate the pedestrian movement across this underneath space in case C-3. Although the bus stops are very close to this pedestrian crossing, there are no demarcated bus bays. Thus, it creates unnecessary traffic, which disturbs the pedestrian movement and makes them uncomfortable to use it. Vehicle parking underneath this space also creates disturbances to the pedestrians.

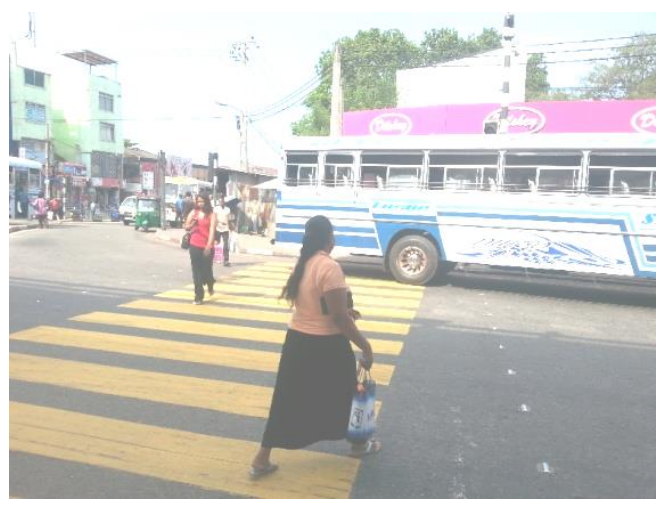

Fig 22: Pedestrian crossings are blocked by buses- (C3-DF) Source: Author

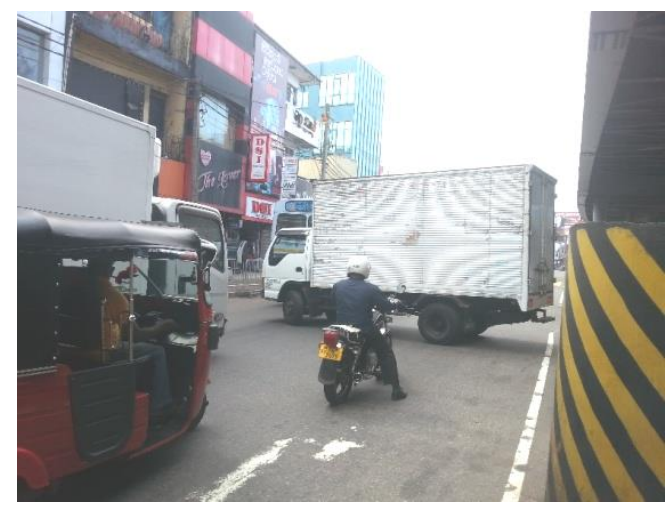

Fig 23: Road is blocked by vehicles from Underneath parking area- (C3-DF) Source: Author

When comparing the cases by observations and user perceptions, it shows that open side spaces (ex-C1-BJ) are more accessible than open middle space (ex-C2-KJ, C4-MJ) and underneath middle space (ex-C3-DF).

\section{Security Level: in terms of vehicular traffic \& social environment}

As shown in the results of user perception, $\mathrm{C} 1-\mathrm{BJ}$ is the highest secured place in terms of vehicular movement and social environment while C3-DF has the lowest values. Further users feel that $\mathrm{C} 2-\mathrm{MJ}$ is secured than $\mathrm{C} 4-\mathrm{KJ}$ and $\mathrm{C} 3-\mathrm{DF}$.

Case1-BJ is safe in terms of vehicular traffic due to a separation from the main road, on street parking lane and pedestrian pavement. During the day-time, activities 
that take place here are visible to everyone. Three wheeler park generally functions during the whole day, due to city hotel customers. Even in the day time three-wheeler drivers are in watchful eyes of the surrounding area. Thus, it is a safe place in terms of social environment. According to their opinions, if this place becomes dangerous people may neglect the place and leaving them any of the hires.

“We don't allow anyone to behave in a disturbing or dangerous manner to people. If this place is named as unsafe, people don't come....definitely we will lose our jobs...."

-Three wheeler driver in the park (personal communication, January 26, 2016)

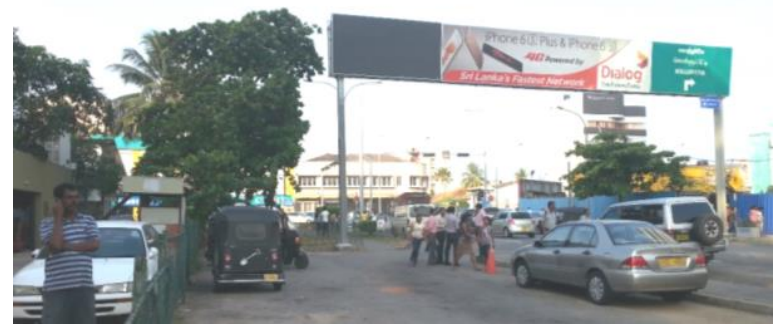

Fig 24: People are waiting and moving - C1-BJ Source: Author

Respondents believe that case 2-KJ isn't safe due to heavy traffic flow surrounding main roads. Further some people believe that this is a safe place due to its' openness, visibility but it isn't a safe space in terms of social environment caused by lack of proper lighting during night time. Although it is junction, there are no street lamps visible. (see Fig. 25)

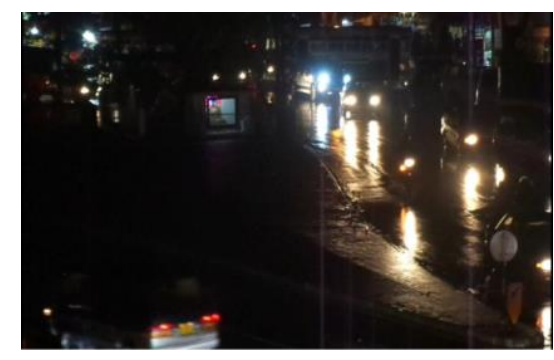

Fig 26: Dark corner spaces at the end of fly over (C3-DF) Source: Author

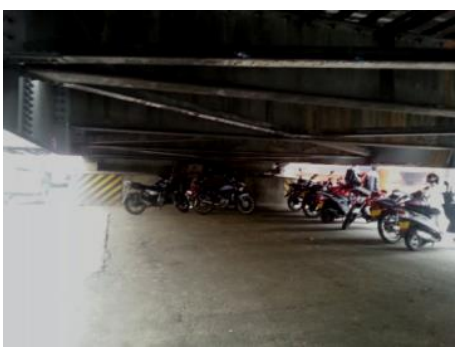

Fig 25: Dark Middle island in night-time $(\mathrm{C} 2-\mathrm{KJ})$ Source: Author

According to respondents, C3- DF is insecure in terms of vehicular traffic due to disturbances caused to pedestrians because of the improper bus stops and parking activity. Further, people believe that this is not a safe space in terms of social environment due to the lack of light during the night time. Although there is a heavy traffic flow in the main roads, users believe that C4-MJ is safe in terms of vehicular traffic. They feel that due to the surrounding boundary fences. Further, due to its openness, people believe that this is a safe place in terms of social environment.

According to the overall user perceptions, there is a better sense of security (safety) from vehicular movement than in a middle space. As a result of this side space, the sense of security from vehicular movement can be increased by physical 
separation like on-street parking, shady tree line. In the case one, there is a sense of security due to on-street parking and pedestrian pathway. In the open, middle spaces, people feel unsafe due to the vehicular movement. When-physical barriers are introduced, the unsafe feeling is reduced. Although the C4-MJ is an open middle space, people feel that it is a safe place from vehicular movement due to fences around that.

\section{Visibility}

Users believe that C3-DF has a lower visibility level while other cases have high visibility level.C1-BJ, C2-KJ and C4 are not covered spaces. As this is an open space, everyone can see the activities happening around. C3-DF is not a fully covered space (covered only on the upper side by the flyover). This is an open space and everyone can see the activities that take place here during the daytime. But the visibility of the corner end is less due to parking activity during the day time. During the night-time, the visibility of corner space is further lessened. It is shown that when visibility level is low, people feel unsafe with regard to the social environment.

\section{Site boundaries}

It is shown that the users feel that C3-DF has no defined site boundary compared to other cases. C3-DF has only a small curb at some areas and has not even that curb in the middle area and the main road are at the same level in those areas. It clearly shows that, defined site boundaries are helpful to increase the sense of security from vehicular movement (ex-C4-MJ).

\section{Neighboring facilities}

Majority of people are using these spaces while they come for neighboring facilities in and around the areas. In C1-BJ, there are the bus stand, parking place and Three-wheeler Park. People come there because of one function, but the facilities in the space are helpful to increase the functionality of that place. 


\section{Impact of usage qualities}

a) Current users of site (no of users, age category) with time-weekday \& weekend

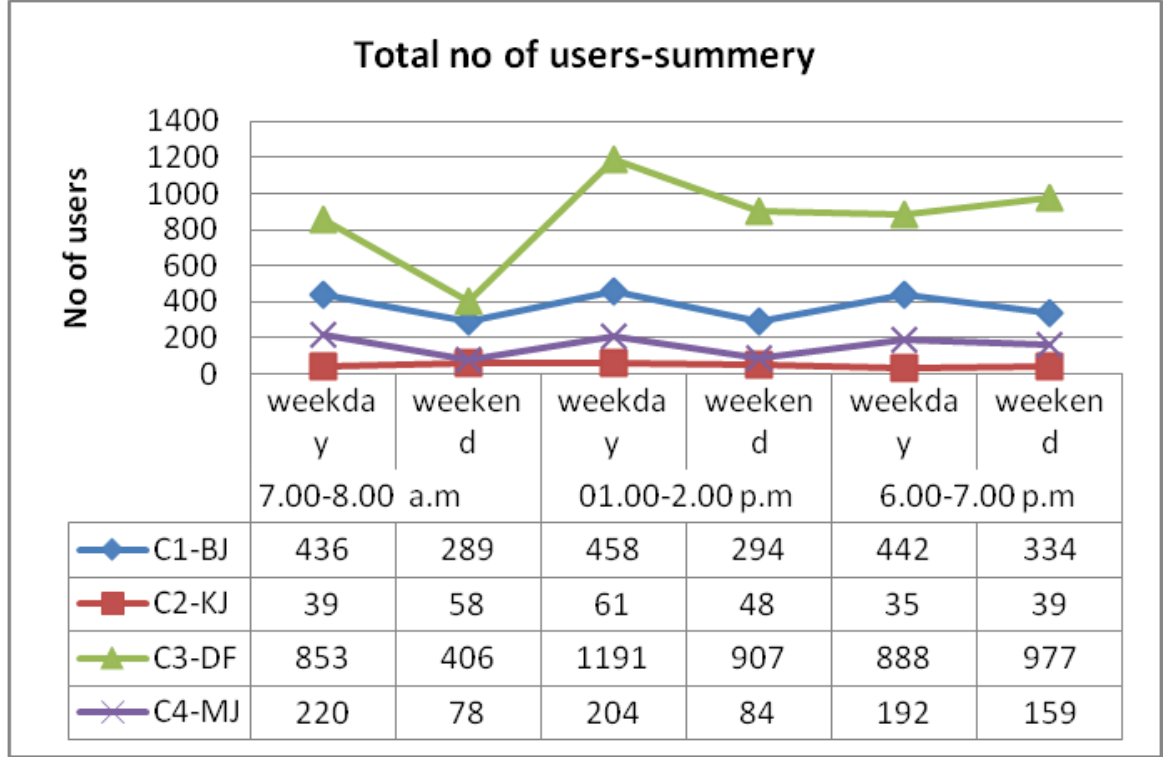

Fig27: Survey result-total no of users-all cases

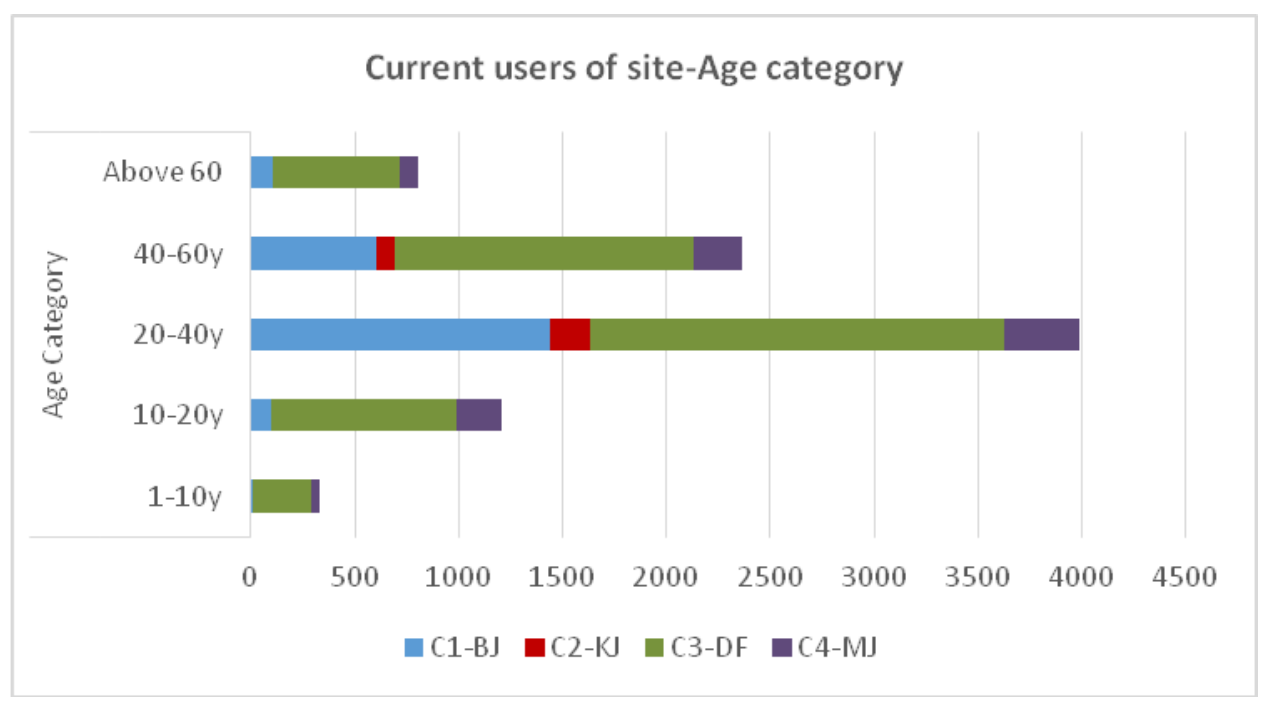

\begin{tabular}{lccrrrr}
\hline Case & \multicolumn{2}{l}{ Age Category } & & & & \\
\hline & $1-10 y$ & $10-20 y$ & & $20-40 y$ & $40-60 y$ & Above 60 \\
C1-BJ & 6 & 97 & 1441 & 603 & 106 \\
C2-KJ & & & 191 & 89 & \\
C3-DF & 286 & 892 & 1992 & 1440 & 612 \\
C4-MJ & 36 & 220 & 360 & 231 & 90 \\
\hline
\end{tabular}

Fig 28: Survey result-total no of users-all cases

Among three cases, the numbers of users are higher in Case 3-DF. During weekdays and weekends there are a larger number of users because it is obligatory to pass this space to reach the other side of the road and facilities have been provided for 
crossing (pedestrian crossings and traffic lights). This place is used by all age categories, genders and it is is an advantage for reclaiming it as public space. Lowest numbers of users are in Case 2-KJ. Majority of users in Case 2-KJ are in the age group 20 to 60 years. The users below 20 years and above 60 years are not using this place. It clearly shows that this place is difficult to be used by children and elderly people due to lack of accessibility.

\section{b) Current use, activity of site weekday and weekend}

Table 6: Survey result- Current use, activity of site weekday and weekend

\begin{tabular}{|c|c|c|c|c|c|c|c|c|}
\hline \multirow[t]{2}{*}{ Case } & \multirow[t]{2}{*}{ Day } & \multirow[t]{2}{*}{ Passing } & \multirow[t]{2}{*}{ Loiters } & \multicolumn{5}{|c|}{ Activities in loiter time } \\
\hline & & & & Talking & Watching & Smoking & Reading & Other \\
\hline \multirow{3}{*}{$\begin{array}{r}\mathrm{C} 1- \\
\mathrm{BJ}\end{array}$} & weekday & 1250 & 86 & 65 & 19 & 2 & & \\
\hline & weekend & 847 & 70 & 57 & 12 & 1 & & \\
\hline & & 2097 & 156 & 122 & 31 & 3 & & \\
\hline \multirow{3}{*}{$\begin{array}{l}\mathrm{C} 2- \\
\mathrm{KJ}\end{array}$} & weekday & 72 & 52 & 2 & 50 & & & \\
\hline & weekend & 132 & 13 & 3 & 6 & 4 & & \\
\hline & & 204 & 65 & 5 & 56 & 4 & & \\
\hline \multirow{3}{*}{$\begin{array}{l}\text { C3- } \\
\text { DF }\end{array}$} & weekday & 2922 & 10 & 6 & 3 & & 1 & \\
\hline & weekend & 2276 & 14 & 11 & 3 & & & \\
\hline & & 5198 & 24 & 17 & 6 & & & \\
\hline \multirow{3}{*}{$\begin{array}{l}\mathrm{C} 4- \\
\mathrm{MJ}\end{array}$} & weekday & 602 & 14 & 9 & 4 & & & \\
\hline & weekend & 317 & 7 & 4 & 3 & & & \\
\hline & & 919 & 21 & 13 & 7 & & & \\
\hline
\end{tabular}

Majority of those who use these spaces are the people who pass by. The numbers of people who use this for crossing the link are higher during the week days than weekends except in C2-KJ. Due to comparatively low traffic flow, people tend to cross that space during the weekends than weekdays. Except in the case 2-KJ most of loiters are talking to each other or use mobile phones while standing or seating in these spaces. In case 2-KJ, users have to spend more time on this middle area due to heavy traffic flow during week days. The users always have to wait and watch for an opportunity to reach the other side of the road.

C1-BJ: Among the users who loiter, most of them just talk to each other or talk over the phone (each other or via cell phone). Some users are waiting for someone or a bus. There is only one seating place at the end of this space near the Galle road. Some users merely use the space to sit.

Case 2-KJ: Most of the time, the users have to wait more than five minutes (generally 5-15 time duration) until they get a chance to cross the road. Although there is a 'Bo 'shrine, it is difficult for people to reach there to worship due to lack of accessibility. According to the observations, most of the bus drivers, conductors and shop owners have to cross this place to reach the other side of the road. Some of them use this space to have a smoke. Some people park their motorcycles under the shading of "Bo" tree and wait a little time. 
Case 3-DF: The owners of parked vehicles in this space spent some time here. Some people stop in this middle space to talk over the phones. Few users stop here and talk with their friends who meet while crossing the road. Some people read newspapers sitting on their motor cycles. Yet, hardly anyone spent more than 15 minutes here.

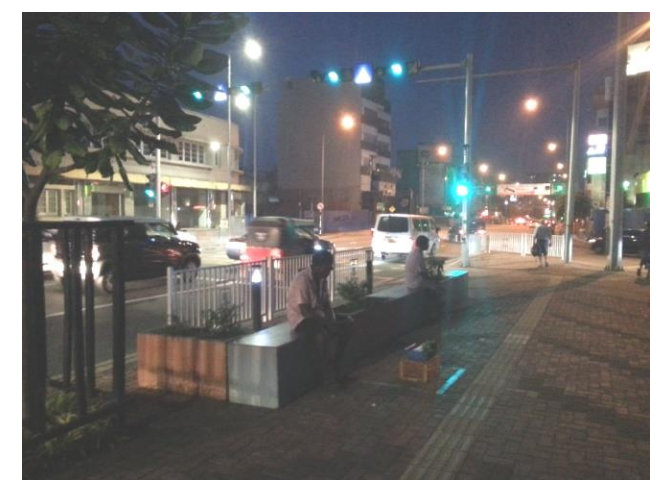

Fig 29: People sitting on benches near Galle road side -C1-BJ.

Source: Author

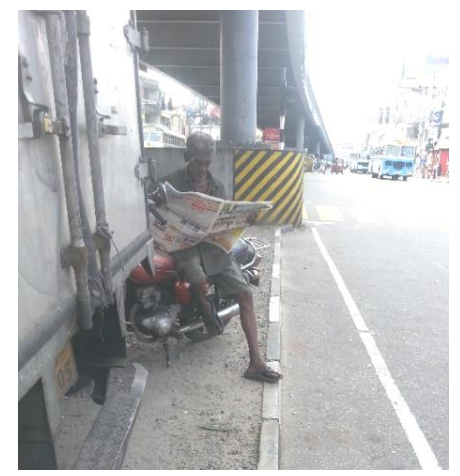

Fig 30: Invented activities in underneath space by people-C3-DF.

Source: Author

Case 4-MJ: During weekends, the number of users increases in the evening due to low traffic flow and its easy accessibility. During the weekday evenings, people come into this place to watch trains and sit on the steps of the existing statue while chatting with each other. In the after noons, the cleaning workers sit on the stones under the small tree here and chat with each other for some time.
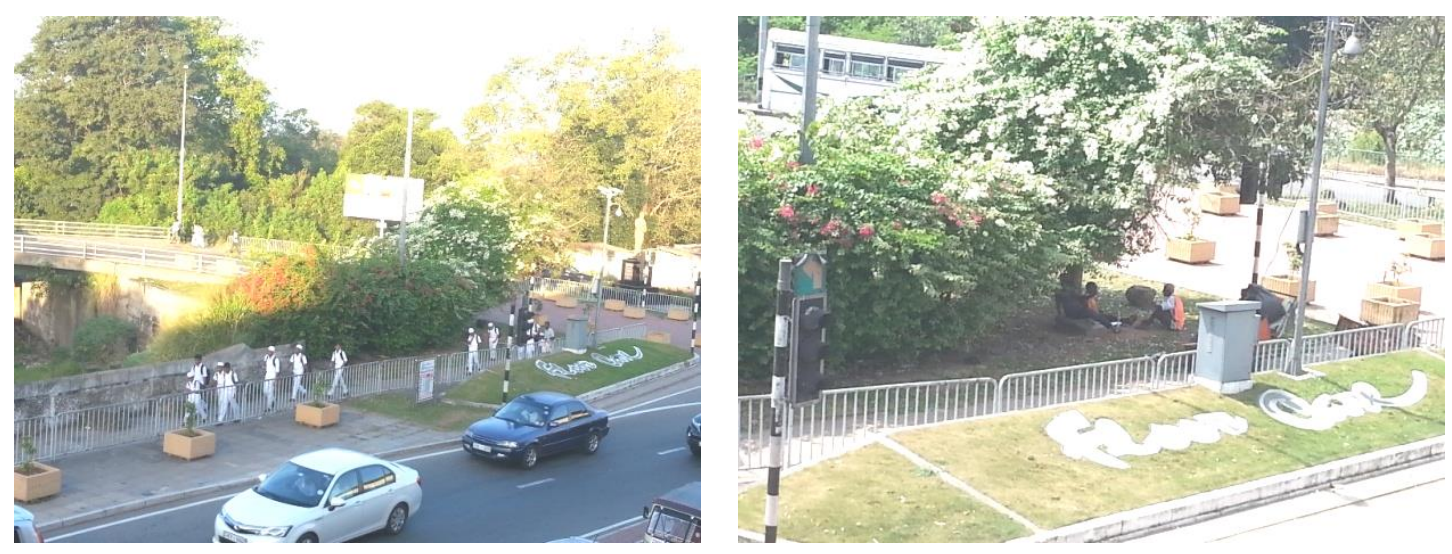

Fig32: People are seating under the shaded area and chatting.

Source: Author 


\section{Reasons for existing residual qualities}

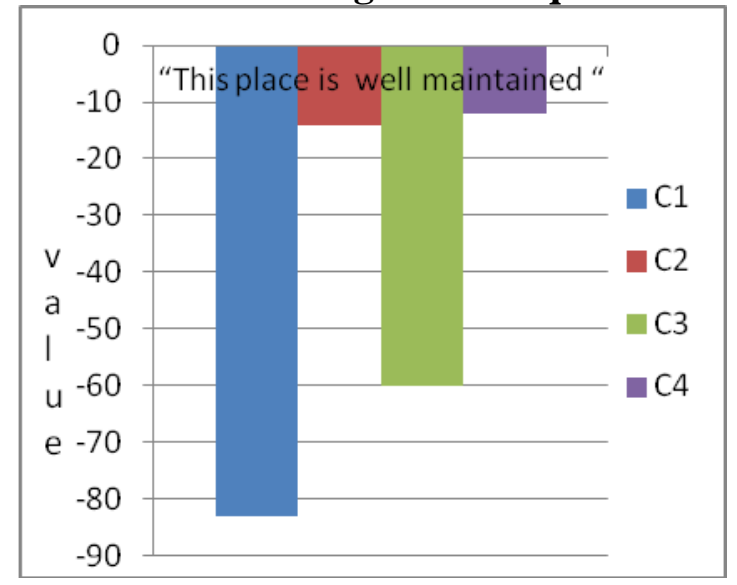

Fig 33: User perception regarding maintaining of the space. Source: Author

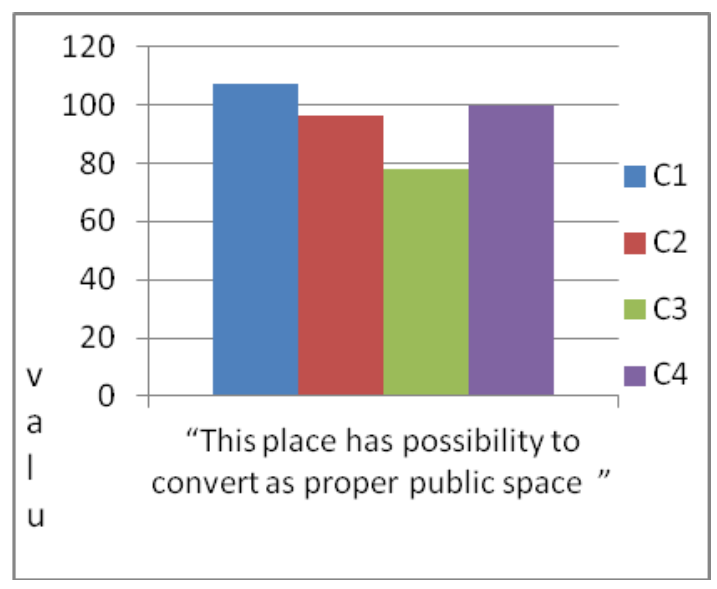

Fig 34: Possibilities for reclaiming as public space.

Source: Author

All the respondents believed that the places are not maintained properly and the places have reclaiming possibility as public spaces. The case $1-\mathrm{BJ}$ is maintained by the Municipal Council and private vehicles are not permitted to park in the CTB bus stand but people park their private vehicles there. The place is not properly cleaned and it does nothave properly-controlled parking activity. Case 2-KJ, case 3DF and case 4-MJ belong to RDA and are maintained by the Municipal Council. In Case 2-KJ, there are no street lamp posts or pedestrian crossings towards the 'Bo shrine'. Although it is not properly maintained, the main reason for the residually is low accessibility to the island. In the case 3-DF, the existing parking facility is not properly supervised. Some heavy vehicles are parked here the whole day. Even at night time, this space is not lit up properly and this darker environment is a threat and the pedestrians are insecure. In the case 4-MJ, there are flower pots here as landscape elements. However, they are used as a decoration. It is better to make shadings from a landscape point of view.

There are boards mentioning the sponsored private companies for the maintenance of case 1-BJ and case-MJ. However, they do not seem to work properly.

\section{Possibilities for reclaiming as public space}

All of the respondents believed that the places are not maintained properly and the places have reclaiming possibilities as public spaces. Thus, the selected four case studies can be summarized as below.

\section{C1-BJ}

Majority are expecting a place for seating, waiting with shading (58\%) to spend until they stay there for a little time. It lacks proper seating spaces except the bench near the Galle Road side which is also not shaded. Due to the hot climate, it is important to provide shading spaces with seating arrangement in urban spaces as 
such. The place already has potential to develop as a shaded space without covering it by fences.

$32 \%$ of respondents proposed to introduce small facilities like milk bars, food outlets, newspaper shops and lottery kiosks, which may attract users. Before the new traffic plan, there was a small milk stall and a lottery kiosk at the corner of this place, which was functioning well. Several people mentioned about the milk shop and lottery kiosk in their interviews, which proves that it might have been functioning really well.

Finally, it appears that this place needs small additional supportive activities/functions to strengthen the existing potentials as public space.

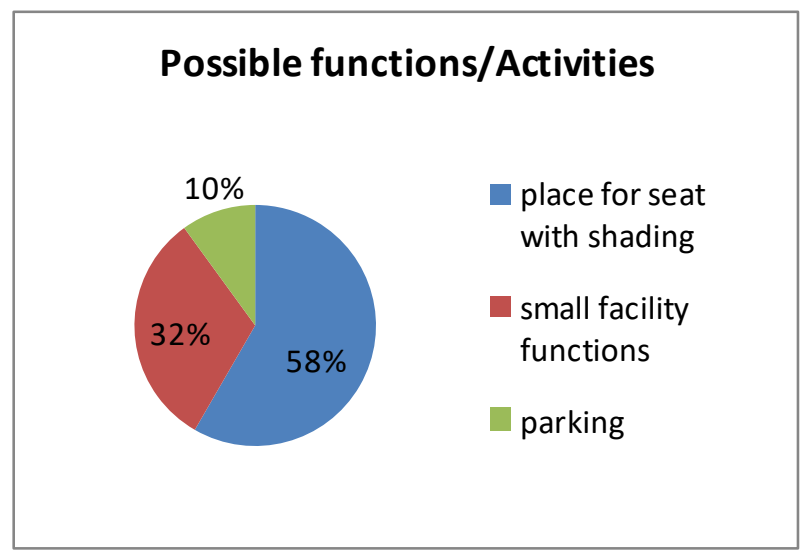

Fig 35: Survey result-possible functions/activities-BJ Source: Author

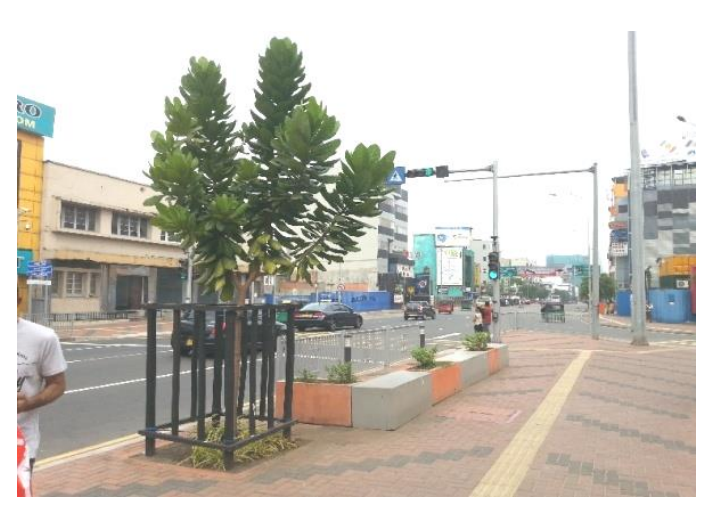

Fig36: Cement benches near Galle road Source: Author

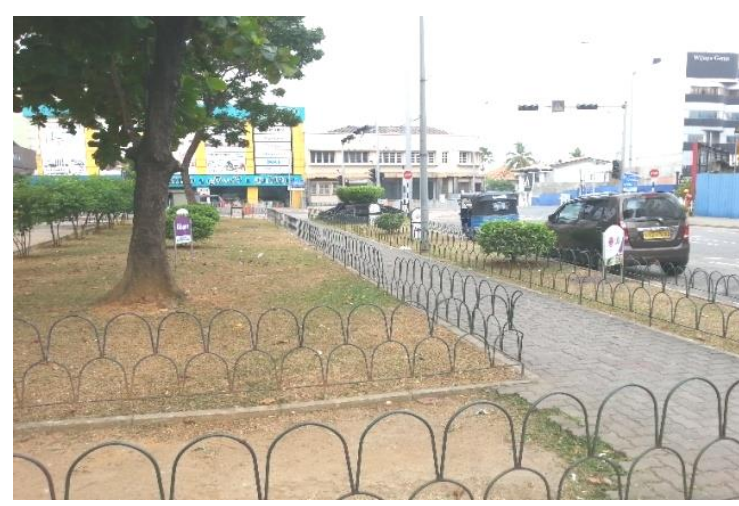

Fig37: Lawn are covered by fences Source: Author

\section{C2-KJ}

Majority are expecting a connecting point with pedestrian movement $(60 \%)$. They expect a solution like underpass, bridge, pedestrian crossing. $40 \%$ of respondents proposed an open, landscaped area. They expect a water feature, information boards...etc. in this space. However, it appears that it is a solution needed 
to access this place if it is converted as a proper public space. Maintenance problems like lighting up at nighttime can be solved easily. Otherwise, this place could be an open landscaped area, which discourages people to use it.

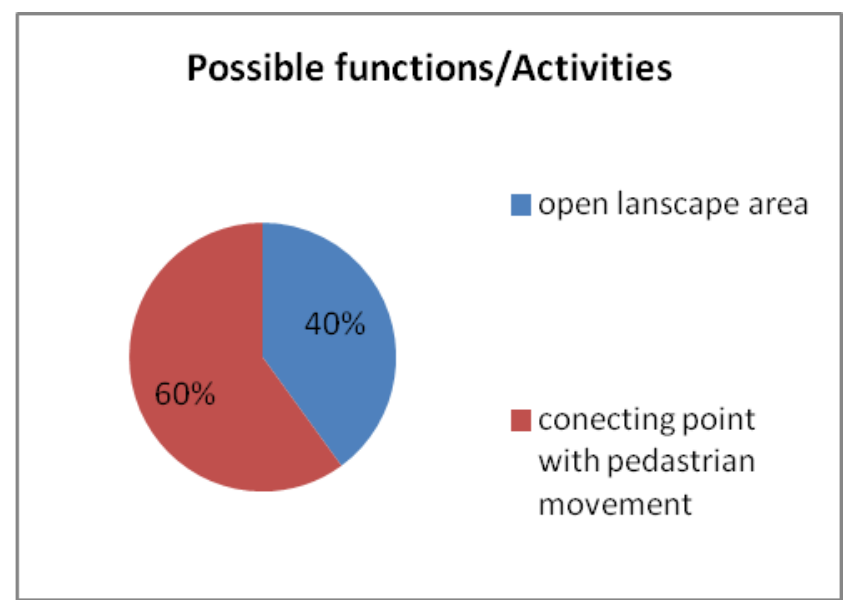

Fig38: Survey result-possible functions/activities-KJ Source: Author

\section{C3-DF}

Majority (33\%) is expecting an open landscape area (painting the bridge with colors, flower fence etc. $23 \%$ of respondents proposed to remove the existing parking function. Small facility functions like lottery kiosk, drainage and pavement improvement, seating facilities for passengers are other proposed functions by the respondents.

High pedestrian movements can be seen here. Thus, it is important not to block this movement by vehicle parking. Removing existing parking block is important because it create traffic in the vicinity. It is also important to introduce bus bays to prevent traffic congestion and make pedestrians feel insecure. It is important to build some obstructions to prevent vehicle parking in the middle island spaces, which are allocated for pedestrian movement. It can be done in an aesthetically pleasing way to the context without conventional steel barriers. Other than painting the bridge with colors, this underneath space can be used for street art. 


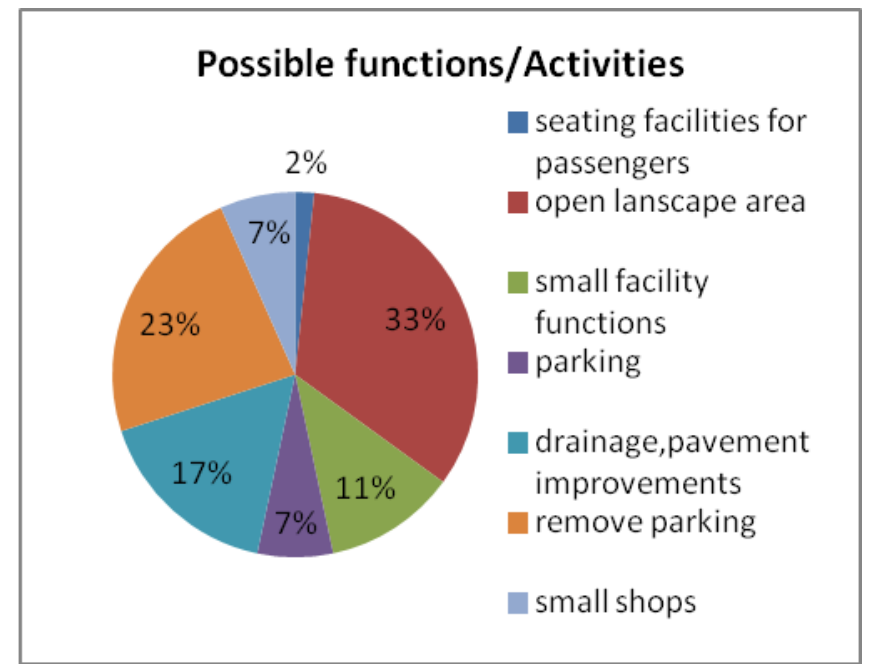

Fig 39: Survey result-possible functions/activities-DF Source: Author

\section{C4-MJ}

A greater percentage $(47 \%)$ is expecting a place for seating with shading to spend some time here. There is no place for waiting, expecting some one or meet someone around this junction even though there is a railway station. The railway passengers expect a place to spend some time other than standing in front of the railway station. The shop owners of the pedestrian bridge had some negative perception regarding the above garden idea. They think that if it is covered by bushes and trees it could be a place for illicit activities in the middle of the town. However, it is clear that there is a need for a landscape area with some kind of shade with seating. However, it should maintain the quality of openness as it was important for a safe public place.

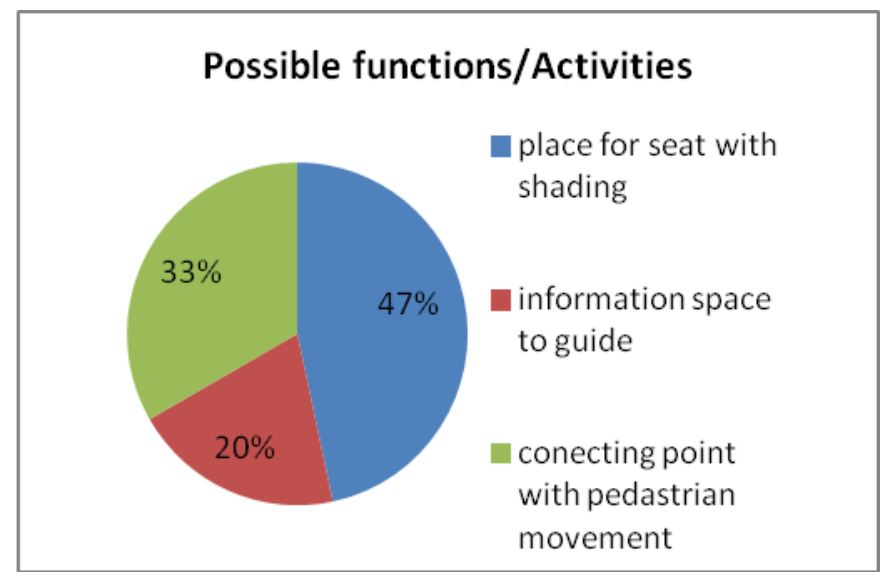

Fig40: Survey result-possible functions/activities-MJ Source: Author

$33 \%$ of respondents are expecting a connecting point with pedestrian movement here. According to their views, it would be used as an underground pathway. However it has a potential to combine with existing movement patterns and key supportive functions like cinema, theatres, railway station, school, trace expert city which surrounding here. $20 \%$ of respondents are expecting informative items like 
displaying railway timetable etc...to be aware of the train schedules easily. However, it should be done without creating disturbance to the drivers.

\section{POSSIBLE INTERVENTIONS FOR RECLAIMING}

Open side spaces have a better sense of security (safety) from vehicular movement than in a middle space. As a result of this side space the sense of security from vehicular movement can be increased by physical separation like on street parking, shady tree line etc...In case one, there is a sense of security due to on street parking and pedestrian pathway. In such side space, the required additional supportive activities/functions strengthen the existing potentials. Then the optional activities may be increased and it leads to the improvement of social activities.

In open middle spaces, people feel unsafe due to vehicular movement. When physical barriers are introduced, the unsafe feeling is reduced. Although the C4-MJ is open middle space people feel that it is a safe place from the vehicular movement. In the middle space, accessibility is a main issue, which causes comparatively low usage of the space leading to being residual. Then the users could be limited to some age category. In C2-KJ, most users are 20 to 60 yrs but when increasing the size of the middle space with safe atmosphere, people tend to use it neglecting its difficulty of access (ex-C4-MJ). It is a solution needed to access-these middle places if it is converted as proper public space.

When considering similar type local examples suitable for C4-MJ, Rajagiriya Children's Park seems to be a successful open middle space as a public space. Rajagiriya Children's Park has positive features in terms of public space. It has three pedestrian accesses from three directions to the place so all age categories can access there easily while it generates a safer feeling without any interference of vehicular movement. There is a level deference between pedestrian paths and the play area. It also provides some secure feeling from the vehicular movement. It has children's play spaces in the middle space. Playing is the optional activity here. Shady trees, seating arrangements, pedestrian crossings, and surrounding pedestrian paths provide better a physical environment. Therefore, the place helps to increase social activities like gathering, discussing, watching children play etc. Comparatively, the area of the land in Rajagiriya is higher than C4-MJ and C2-KJ. Therefore, it has enough area for the activity. However, C4-MJ has comparatively lager area than $\mathrm{C} 2-\mathrm{KJ}$. The usable area of C4-MJ could be increased by using the void ('sites out of sight' according to Crisman, 2005). In the cases like C4-MJ, the middle place may be a connecting point of pedestrian movement with easy pedestrian accesses, improved buffer zone like pedestrian pathway in between road and middle space. It has to be a place, which facilitates people for optional activities like seating, rest and spend some time in the busy urban environment.

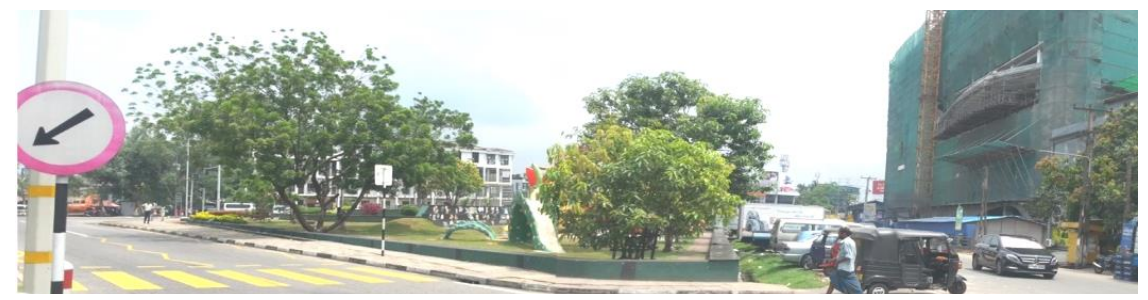

Fig 41: C-1 Rajagiriya Children's Park with surrounding pedestrian path, on street parking and elevated functional space

Source: Author 


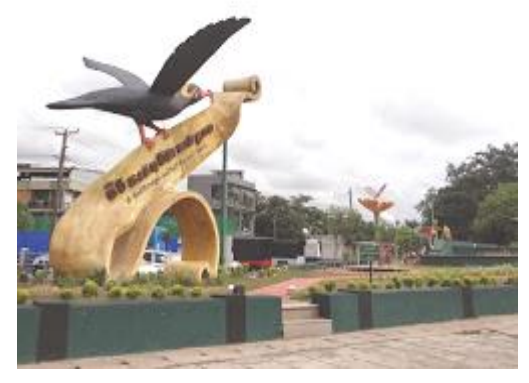

Fig42: C-2 elevated functional space-Rajagiriya Children Park Source: Author

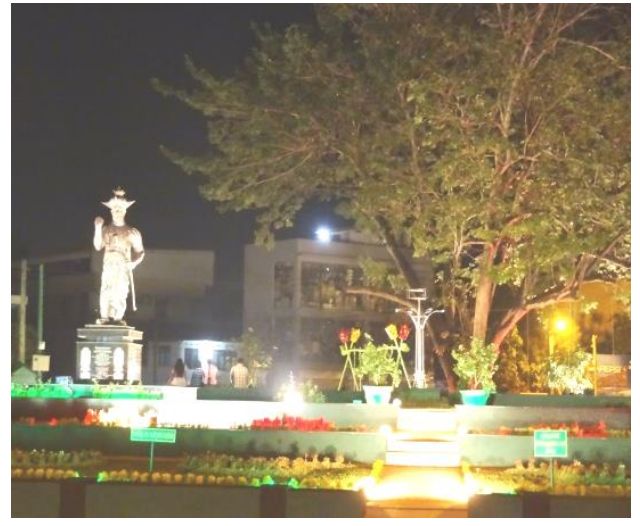

Fig43: C-3 light up functional area at night time Source: Author

The places like $\mathrm{C} 2-\mathrm{KJ}$ could be an open landscaped area, which discourages to cross this space. In a narrow space, it could be effective. Example is C2-KJ. However, for the cases $\mathrm{C} 4-\mathrm{MJ}$, it is not a proper solution because it is comparatively a larger space. When considering similar type local examples suitable for $\mathrm{C} 2-\mathrm{KJ}$, there are some positive features in the Rajagiriya middle spaces along the main road and the middle space in Panchikawatta. Rajagiriya middle space is less elevated, with a lawn area in between the two roads. Because of the high elevation, people cannot cross the space and disturb to the traffic flow and discourage dangerous pedestrian movements. The height also does not disturb the views of drivers. Although it is elevated, the vehicle can be seen from the other side from the driver's eye level. The Panchikawatta middle place is used to build-up the image of the area. A horse sculpture, made from vehicle parts is used as a monument at a higher elevation. (Panchikawaththa area is popular for spare parts sales). If it is not providing accessibility because of traffic related solution, the solution might be a combination of Panchikawatta and Rajagiriya middle space. The small middle space like C2-KJ might have the features, which discourage people to cross this space while helping to enhance image of the area as visual usage of the space.

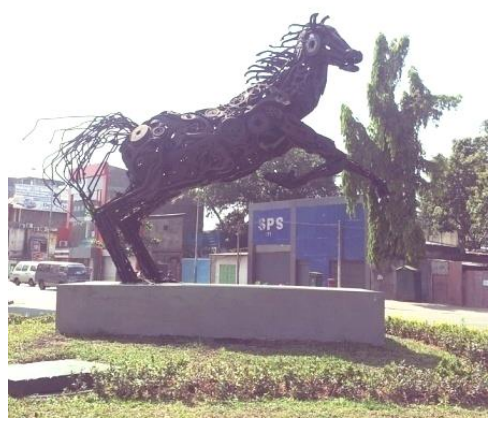

Fig. 45: C-4 Panchikawaththa middle space-residual space as used for enhance immovability.

Source: Author

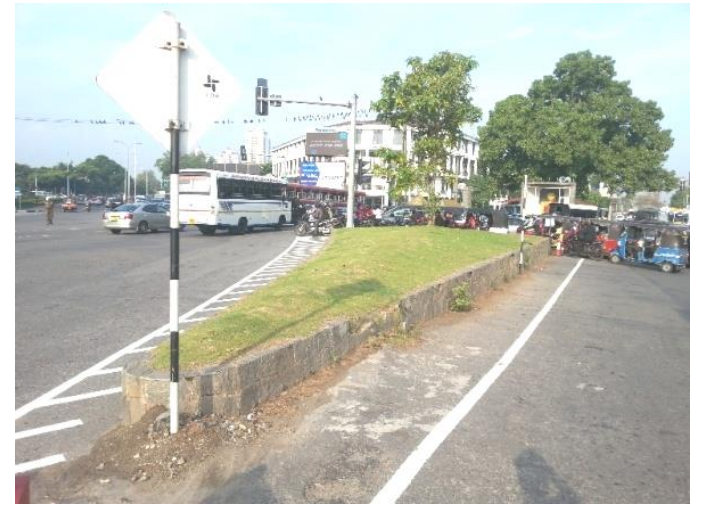

Fig. 46: C-5 Rajagiriya middle space-elevated space to prevent crossing. Source: Author 
Underneath middle spaces like in C3-DF, people feel difficult to access due to parking of vehicles. It is important to build some obstructions to avoid vehicular parking in the middle island space which is allocated for the pedestrian movement. Generally, underneath space of flyovers have pedestrian crossings to facilitate the pedestrians and a large number of pedestrians use to cross this kind of spaces. Therefore, it is different from open middle spaces like C2-KJ and C4-MJ. It is necessary for the movement because of orientation of flyovers. Generally, those underneath spaces are shady spaces from any weather conditions. Hence, it could be used for optional activities related to public art, small seating arrangement for resting and to spend some time under the shade. This solution may be a combination with physical and visual usage because the fly-over eventually becomes an urban element. It is important to avoid hidden corner spaces in day and night time, which will create an unsafe social environment for the users.
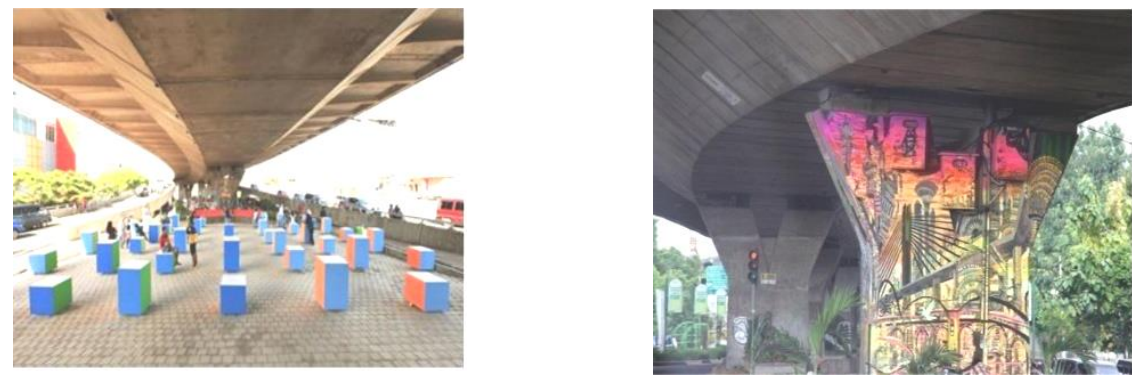

Fig. 47: Parks Pasupati, is a Park located under Pasupati Bridge,Bandung, West Java which has graffiti wall, seating benches for seating and exhibit items Source- https://nadhirajihan.files.wordpress.com/2015/01/105915869.j

\section{Conclusions}

Open side spaces are the most reclaimable category than middle and underneath spaces due to physical characteristics. Accessibility is a main physical character, which caused comparatively low usage of the space lead to being residual. Then the users could be limited to the age category 20 to 60 years. Users have a low sense of security (safety) from vehicular movement in a middle space than a side space. The sense of security from vehicular movement can be increased by physical separation like on street parking, shady tree line and pedestrian pathway etc. All created spaces have to be visible properly during day and night time. Then it has a sense of security due to its openness and not encouraging improper activities. Visibility is there in most of the traffic related residual spaces. The traffic related reclaiming possibilities could be divided in to physical and visual usage. For underneath spaces, the solution may be a combination with physical and visual usage. The size of the middle open space helps its usage. People tend to use comparatively large size of middle space with safe atmosphere from vehicular movement than small middle space. Small middle space might have the features, which discourage to cross this space while helping to enhance the image of the area (urban image) as visual usage of the space. 
Additional supportive activities / functions strengthen the existing potentials for reclaiming. Thus, the optional activities should be increased to improve social activities. All traffic related residual spaces have 'appropriation', which was explained by Aranyali (2009). Spatial qualities like accessibility, security, area of the site and visibility are the main factors that causes 'appropriation' related to traffic related urban residual spaces. Based on that appropriation, it is possible to improve those activities if suitable. If there is a necessary usage, it is a greater potential for reclaiming. When introducing optional activities as reclaiming possibility, the physical quality of the space must be improved for facilitating lack of maintenance and residual qualities. Well-organized, public-private partnerships among traffic related, and maintenance related statutory bodies and private sector will help evade residual symptoms and better management and control of reclaimed public spaces.

This study is limited to residual open spaces (Open side space and Open middle space and open underneath space) in urban areas of Colombo administrative district which are being created by traffic related needs. Since this is a basic study, four cases_were selected as a representative sample of reclaiming possibilities for the public use. However, the validity of the study will enhance if more cases for different types are examined. Further, this study could be developed to study about reclaiming possibilities of non-traffic related residual spaces.

\section{References}

Alanyali, E. (2009) Redefining Leftover Space: Value and Potentiality for the City: VDM Publishing, 3639144953, 9783639144956

Carmona, M. (2010) "Contemporary public space: critique and classification, Part one: critique", Journal of urban design, Vol.15, no.1, pp. 123-148

Carr, S,Francis ,M., Rivlin, L.G., \& Stone,M.A. (1992) Public space. USA:Cambridge University Press

Crisman, P. (2005) "Site Out of Mind: a Pedgogy for Seeing + Representing," in Encounters/Encuentros/Recontres, Washington, DC: ACSA Press. pp. 244- 258

Doron, G. (2007) Dead zones, outdoor rooms and the Architecture of transgression, in Loose Space: Possibility and diversity in urban life, London \& New York: Routledge. pp. 210- 229

Franck, K. and Stevens, Q. (ed.) (2007), Loose Space: Possibility and diversity in urban life, London \& New York: Routledge

Gehl, J. (1987) Life Between Building. Comphengen: Danish Architetural press

Groth, G. and Corijn, E. (2005) "reclaiming urbanity: intermediate Spaces, Informal Actors and Urban Agenda Setting", Urban Studies, Vol. 42, pp. 503- 526

Kamvasinou , K. (2011) "The public value of vacant urban land", in Municipal Engineer: Proceedings of the Institution of Civil Engineers . (pp. 157- 166) Scotland: ICE Publishing

Khalil ,M.H., \& Eissa, D.M., (2013) Reclaiming Residual Spaces for the Public: a Case Study from the City of Cairo .Proceedings of the International Conference on cities, people and placesColombo. (pp. 105- 121). Colombo, Sri Lanka: University of Moratuwa

Korosec-Serfaty P. (ed) (1976). "Protection of Urban Sites and Appropriation of Public Squares" in Appropriation of Space, Proceedings of the 3rd International Architectural Psychology Conference - Strasbourg (pp. 46-61). Strasbourg-France: CIACO.

Loukaitou-Sideris, A. (1996) Cracks in the city: Addressing the constraints and potentials of urban design, Journal of Urban Design, Vol.1, no.1, pp. 91-103

Madanipour, A. (1996) Design of urban space: an inquiry to a socio-spatial process, USA: John Wiley $\&$ Sons.

Madanipour, A. (ed.) (2010), Whose Public Space? International Case Studies in Urban Design and Development, London \& New York: Routledge

Rivlin, L., (2007) Found Spaces: Freedom of choice in public life, in Loose Space: Possibility and diversity in urban life, London \& New York: Routledge, pp. 38-53

Sola Morales, I. (1995) "Terrain Vagues". in Anyplace, Cambridge, MA: MIT Press. 118-123 
Trancik, R. (1986), Finding Lost Space: Theories of Urban Design, New York:

Tuan,Yi-Fu. (1977) Space and Place: The Perspective of Experience. Minneapolis: University of Minnesota Press, Van Nostrand Reinhold

Winter bottom, D. (2000) Residual space re-evaluated, Places, Vol.13, no.3, pp.40-47

Winterbottom M. (2000) More problems in Quintilian, Bulletin of the Institute of Classical Studies,

Blackwell Publishing Ltd, 44: 167-177. doi:10.1111/j.2041-5370.2000.tb00602.x 